\title{
Biocultural Practices during the Transition to History at the Vat Komnou Cemetery, Angkor Borei, Cambodia
}

\author{
$\mathbf{\Lambda} \cdot \mathbf{\Delta} \cdot \mathbf{\Lambda}$ \\ Rona M. Ikehara-Quebral, Miriam T. Stark, William Belcher, Voeun Vuthy, \\ John Krigbaum, R. Alexander Bentley, Michele Toomay Douglas, and \\ Michael Pietrusewsky
}

\begin{abstract}
Mainland Southeast Asia underwent dramatic changes after the mid-first millennium B.C.E., as its populations embraced new metallurgical and agricultural technologies. Southeast Asians transformed their physical and social environments further through their participation in international maritime trade networks. Early state formation characterized much of the mainland by the mid-first millennium C.E. We examined a protohistoric (200 B.C.E. -200 C.E.) skeletal sample from the Vat Komnou cemetery at Angkor Borei in the Mekong Delta (southern Cambodia) to understand the health impacts of this changing environment. Degenerative joint disease patterns indicate a distinct sexual division of labor. Although intentional dental filing was practiced, its impact on oral-dental health could not be determined. Dental pathologies suggest a mixed diet with more fibrous foods and a lower reliance on soft, processed agricultural foods. A broad-spectrum diet and varied use of the local environment are inferred from the faunal evidence. Stable isotope ratios indicate a relatively greater reliance on fish and estuarine dietary resources than on terrestrial protein. Affinities with other groups in the region are suggested by the cultural practices of the relatively tall, healthy inhabitants from Vat Komnou. KeYwords: bioarchaeology, biocultural studies, Cambodia, Southeast Asia, Iron Age, health, dental filing, fauna, diet, stable isotope analysis, sexual division of labor.
\end{abstract}

\section{INTRODUCTION}

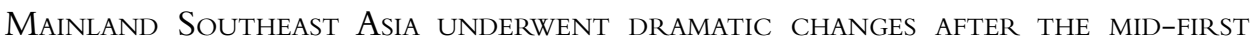
MILLENNIUM B.C.E., as its populations embraced new metallurgical and agricultural

Rona M. Ikehara-Quebral is a Senior Bioarchaeologist at International Archaeological Research Institute, Inc. in Honolulu. Miriam T. Stark is a Professor of Anthropology at the University of Hawai'i at Mānoa. William Belcher is an Assistant Professor of Historic Archaeology at the University of Hawai' $i$ at West O'ahu. Voeun Vuthy is a Director of Archaeology at the Ministry of Culture and Fine Arts in Phnom Penh, Cambodia. John Krigbaum is an Associate Professor of Anthropology at the University of Florida, Gainesville. R. Alexander Bentley is Chair of the Department of Anthropology at the University of Tennessee, Knoxville. Michele Toomay Douglas is an affiliate graduate faculty at the Department of Anthropology, University of Hawai'i at Mānoa. Michael Pietrusewsky is Professor Emeritus at the Department of Anthropology, University of Hawai' $i$ at Mānoa. 
technologies (Stark 2006a). Its physical and social environment was further transformed by the emergence of international maritime trade and socio-political reorganization associated with early state formation (Stark 2003, 2004). The wideranging variability in mortuary treatment, construction of moderate-scale earthworks around large settlements, beginning of specialized metal production, and appearance of regional settlement hierarchies during the period 500 B.C.E. -500 C.E. provide strong evidence for an emerging socio-political complexity in Mainland Southeast Asia (Kim 2013; Manguin 2004). During Cambodia's transition to history, such a dynamic environment would have affected the health of inhabitants of the region as they adapted to changing roles.

To understand the health impacts of this changing environment, we examined a skeletal sample from the Vat Komnou cemetery at the Angkor Borei site in southern Cambodia, located on the western edge of the Mekong Delta (Fig. 1). The earliest documented occupation of Angkor Borei, within which Vat Komnou is located, dates to the mid-first millennium B.C.E. (Stark 2003; Stark and Bong 2001). The Vat Komnou cemetery dates from 200 B.C.E. -200 C.E. (Stark 2006b:100), which falls within the Protohistoric or Early Historic Period, c. 500 B.C.E. -500 C.E. (Table 1). The "Protohistoric Period," in reference to evidence of early state formation in the Mekong Delta (Stark 2004:91), is synchronous with the "Iron Age" in Mainland Southeast Asia (Higham 2014:196-269; O'Reilly 2014). Both terms will be used as the various scholars intended in the works cited here.

Interaction between biology and behavior remains a central theme in bioarchaeology, with particular attention to influences of environment and culture on human biological variation (Larsen 2002). The goal of this research is to investigate the biological implications of cultural practices (i.e., the "biocultural" environment) using the skeletal and dental data recorded from the Vat Komnou cemetery sample at Angkor Borei. How did cultural practices, such as sexual division of labor, modification of teeth, and diet, affect people's health during the Protohistoric Period? In this article, we review human skeletal, zooarchaeological, and botanical data, which has been produced by the Lower Mekong Archaeological Project (hereafter LOMAP) since 1996, to study environmental change and past human responses in the northern Mekong Delta and neighboring regions, with an emphasis on comparative osteological patterning.

\section{PHYSICAL ENVIRONMENT}

Mainland Southeast Asia's climate is dominated by seasonal tropical monsoons that affect agricultural production. Most large settlements during the Protohistoric/Iron Age Period were concentrated in either coastal areas, major floodplains and river valleys, or around the perimeters of freshwater lakes (Stark 2001a). Much of Vietnam's Mekong Delta would have been uninhabitable until the early centuries C.E. (Reinecke 2012:252), while the delta's northern and western fringes (in Vietnam and Cambodia) could have been settled by c. 4000 B.P. Mounded settlements in the floodplain areas have been documented in both Thailand and the Mekong Delta; these could have supported large populations through rainfed and flood recession agricultural strategies (Stark 2006a:414). Cambodia's lowlands are defined by the Tonlé Sap (the largest freshwater lake in Southeast Asia) and the Mekong River. During the annual rainy season, Cambodia's floodplains are partially inundated, providing excellent conditions 


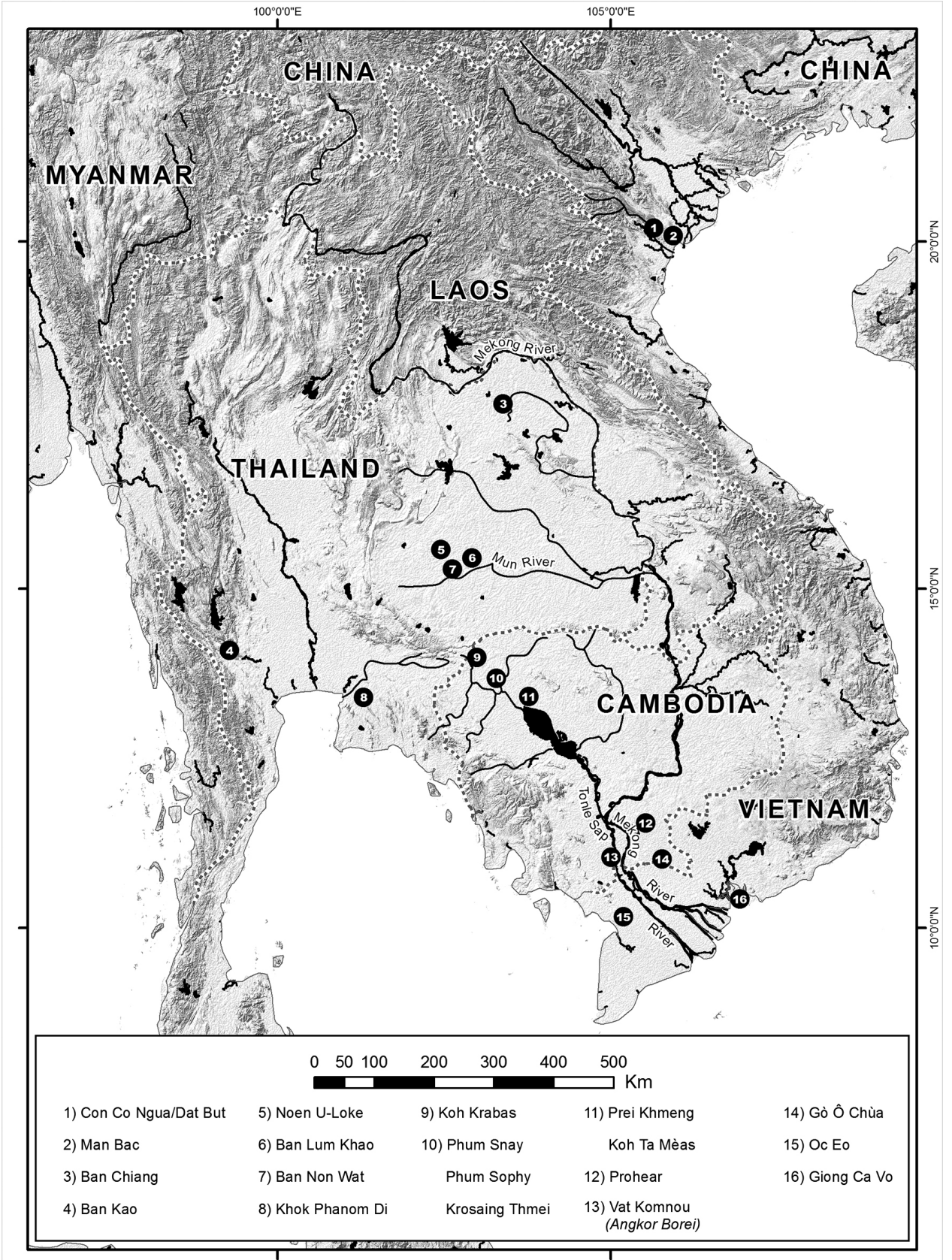

Fig. 1. Map of Mainland Southeast Asia showing archaeological sites discussed in this paper. Drawn by Matthew Bell, IARII. 
Table i. Southeast Asia Chronology (adapted from Stark 2004)

\begin{tabular}{|c|c|c|}
\hline TIME PERIOD & DATES (B.C.E./C.E.) & CULTURAL DEVELOPMENTS \\
\hline Late Hoabinhian & c. 5200-2000 B.C.E. & $\begin{array}{l}\text { Late Paleolithic, terminal, and post- } \\
\text { Pleistocene life based on mobile hunting } \\
\text { and gathering with increasing settlement } \\
\text { along coasts. }\end{array}$ \\
\hline Neolithic and Bronze Age & c. $2000-500$ B.C.E. & $\begin{array}{l}\text { Introduction of agriculture and settled } \\
\text { village life, basically with a stone } \\
\text { technology; bronze working from c. } \\
1500-1000 \text { B.C.E. }\end{array}$ \\
\hline Protohistoric/Iron Age & c. 500 B.C.E. -500 C.E. & $\begin{array}{l}\text { Arrival and local development of iron tools } \\
\text { and weapons, development of } \\
\text { international maritime trade especially } \\
\text { with South Asia. Increasing evidence for } \\
\text { warfare, tools, and development of early } \\
\text { states. }\end{array}$ \\
\hline Pre-Angkorian & c. $500-802$ C.E. & $\begin{array}{l}\text { Appearance of writing using modified } \\
\text { Indian scripts and first Sanskrit, then later } \\
\text { old Khmer language. Expansion of early } \\
\text { states and inter-regional contact. }\end{array}$ \\
\hline Angkorian & c. $802-1431$ C.E. & $\begin{array}{l}\text { Consolidation and expansion of Khmer } \\
\text { empire into much of present-day } \\
\text { Thailand, Laos, and southern Vietnam, } \\
\text { before fragmentation and withdrawal } \\
\text { during conflict with emerging Thai } \\
\text { kingdom. }\end{array}$ \\
\hline
\end{tabular}

for growing rice (Nuttonson 1963:105). Temperatures range from 68 to $97^{\circ} \mathrm{F}$ and humidity is consistently high.

The Angkor Borei site (Takeo Province, Cambodia) is located 5-10 $\mathrm{m}$ above sea level on a marine terrace in the upper portion of the Mekong River delta plain, an area that experienced its first settlement surge in the late centuries B.C.E. (Stark 2006c). This region was characterized by terraces, channels (human and natural), and backswamps (Bishop et al. 2003:360-361; Tamura et al. 2009:328). Scrub forest, grasslands, and marshlands that covered this region between c. 2000-1000 B.C.E. offered abundant wildlife resources for settlers to the community (Bishop et al. 2003; this study). Fish species recovered through LOMAP excavations in 1996, 1999, and 2000 came from natural drainages and ponds; local residents supplemented these natural water features by constructing canals and reservoirs during the settlement's peak occupation.

The Mekong Delta has experienced progradation for the last 6300 years (Tamura et al. 2009:336), but migrating mangrove forests from southern Vietnam that crept northward in the delta may not have reached Angkor Borei by the time populations settled the region in 400 B.C.E. Microfossil and sediment evidence from the cores indicate peak levels of land use intensity and occupation of Angkor Borei occurred prior to the fifth/sixth century C.E. By the late fifth to late sixth century C.E., at the end of the Protohistoric Period, there was a dramatic reduction in grasslands and a corresponding expansion of secondary wet-land forest, signaling a period of decreased land use intensity, changing priorities, or a decreasing population (Bishop et al. 2003:389-390). 
SOCIO-POLITICAL ENVIRONMENT: PROTOHISTORIC/IRON AGE PERIOD IN SOUTHEAST ASIA

Organizational changes that affected Southeast Asia's human populations between c. 500 B.C.E. -500 C.E. included population increase, settlement pattern and subsistence shifts, changes in landscape use, and shifts in economic production distribution patterns. These developments generated qualitatively different mortuary patterns than those documented from previous prehistoric contexts (Domett and O'Reilly 2009; IkeharaQuebral 2010:7-9). Local adoption of iron metallurgy (including iron plowshares and traction technology) undoubtedly affected farming and other subsistence strategies and resulted in the initiation of large-scale public works projects.

Walled settlements associated with water control features such as moats and reservoir channels appeared in several regions throughout mainland Southeast Asia (Kim 2013; Stark and Bong 2001:86). In areas such as northeast Thailand, social stressors such as competition over resources and environmental stressors such as climatic instability may have stimulated intra-regional trade and created demand for a large labor force over short periods of time (O'Reilly 2014). Both types of stressors and localized responses varied across the region. Everywhere, however, centralizing polities engaged with one another to move exotic artifacts, commodities such as salt, and utilitarian crafts along riverine routes (Higham 2014:266-269). With these engagements may have come alliancebuilding over considerable distances (Junker 2004; O'Reilly 2014; Stark 1998).

Such developments took place within a globalizing environment (Stark 2017). From the east, Han Chinese pursued alliances in regions too distant to conquer (Ishizawa 1995). Meanwhile, commercial and religious contact with South Asia, largely via maritime routes, moved people and ideas across Southeast Asia (Junker 2004; Le 2011). South Asian goods appeared in Southeast Asia in the late centuries B.C.E. (Bellina and Glover 2004); geochemical studies of artifacts such as beads indicate that settlements

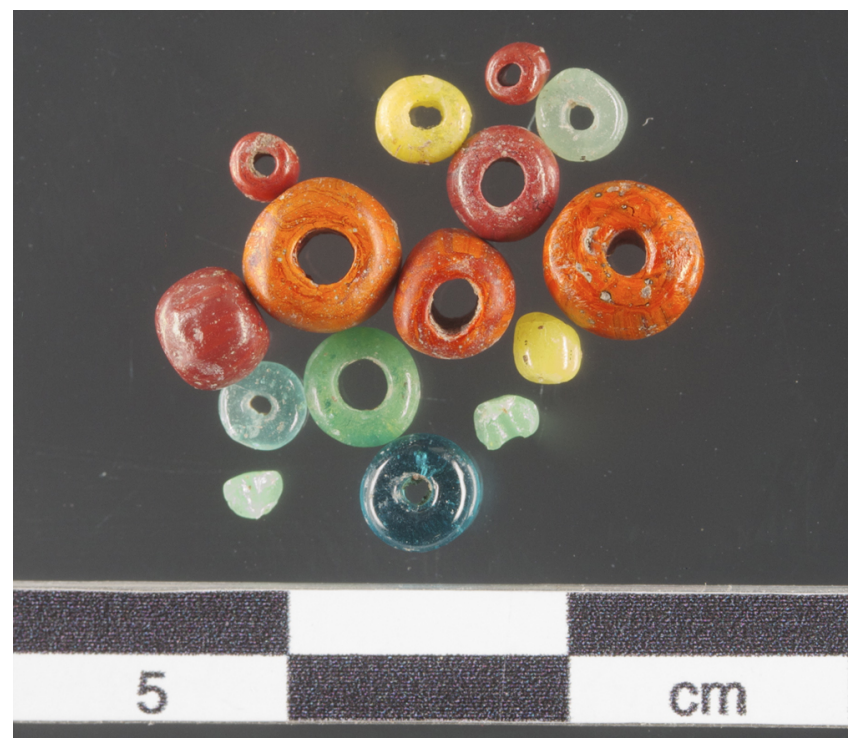

Fig. 2. Beads recovered from Vat Komnou, Angkor Borei. Photo courtesy of Alison Carter. 
across most of mainland Southeast Asia's coasts interacted with South Asia from the second through fourth centuries C.E. (i.e., the time of Angkor Borei) (Bellina 2014; Calo et al. 2015; Carter 2015; Dussubieux and Gratuze 2003). Figure 2 illustrates examples of glass beads recovered from the Vat Komnou cemetery.

By 500 c.E., many of Southeast Asia's coasts and major river valleys housed large populations in large "urban" centers. These urbanized polities involved highly stratified and centralized economic systems; some had full bureaucracies (Manguin 2004; Stark 2006a). Despite dramatic socio-political changes, population stability in multicomponent archaeological sites has been documented in Thailand, Vietnam, and Burma (Kim 2013; Manguin 2009; Stark and Bong 2001).

\section{PROTOHISTORIC PERIOD IN THE MEKONG DELTA}

Archaeological, epigraphic, and art historical research demonstrate that the Mekong Delta was the center of Funan, mainland Southeast Asia's first civilization showing the hallmarks of statehood (Manguin 2009; Stark 2003:89-91). Chinese documentary evidence suggests that the kingdom of Funan emerged in the Mekong Delta, possibly in the late first century C.E. (Ishizawa 1995:14) and flourished as an early state between the second and sixth centuries C.E. (Stark 2003:89). The Funan territory stretched approximately $600 \mathrm{~km}$ along its east-west axis, expanding to c. $2000-2400 \mathrm{~km}$ in the third century C.E., and contained at least a dozen urban centers connected by $200 \mathrm{~km}$ of canals (Stark 2001b:21). Funan is depicted as a powerful, great nation that prospered from maritime trade and inland agriculture, stabilized the southern region, and then declined in the latter half of the sixth century C.E. due to the advancement of hostile forces (Ishizawa 1995:16-18).

Angkor Borei and Oc Eo were two important regional centers during the Funan period. Angkor Borei lies in the northern (Cambodia) side of the Mekong Delta, while Oc Eo cultural sites lie in the southern (Vietnam) side of the delta. Oc Eo was first excavated during World War II by French archaeologist Louis Malleret and more recently by École Française d'Extrême-Orient (EFEO) and Vietnam's Institute of Archaeology. It is considered an important port city of Funan (Manguin 2009; Manguin and Vo 2000). A complex network of rivers and canals connected Angkor Borei and Oc Eo sites. The similarity of the artifacts found at these two archaeological sites suggests early historic interaction and participation in a vast regional system spanning the delta (Carter 2016; Dussubieux and Gratuze 2003; Stark 2003:91). Chinese emissary accounts from third century C.E., local oral traditions, and the higher density of the earliest indigenous inscriptions in the northern part rather than in the swampy southern part of the delta suggest that the political centers of Funan lay to the north in what is now the Kingdom of Cambodia (Ishizawa 1995:16; Stark 2003:91). Angkor Borei remains a strong candidate for one of the ancient polity's capitals, as its social and political importance appears to have continued throughout the subsequent pre-Angkor Period (Stark 2006b, 2006c:312).

\section{VAT KOMNOU, ANGKOR BOREI}

The archaeological remains of an ancient settlement of brick architectural monuments and associated moats and ponds lie beneath modern-day Angkor Borei (Stark 2006c). Angkor Borei spans approximately 300 ha and contains over 100 water features (Stark and Bong 2001). Three areas of Angkor Borei were excavated from 1999 to 2000 by 


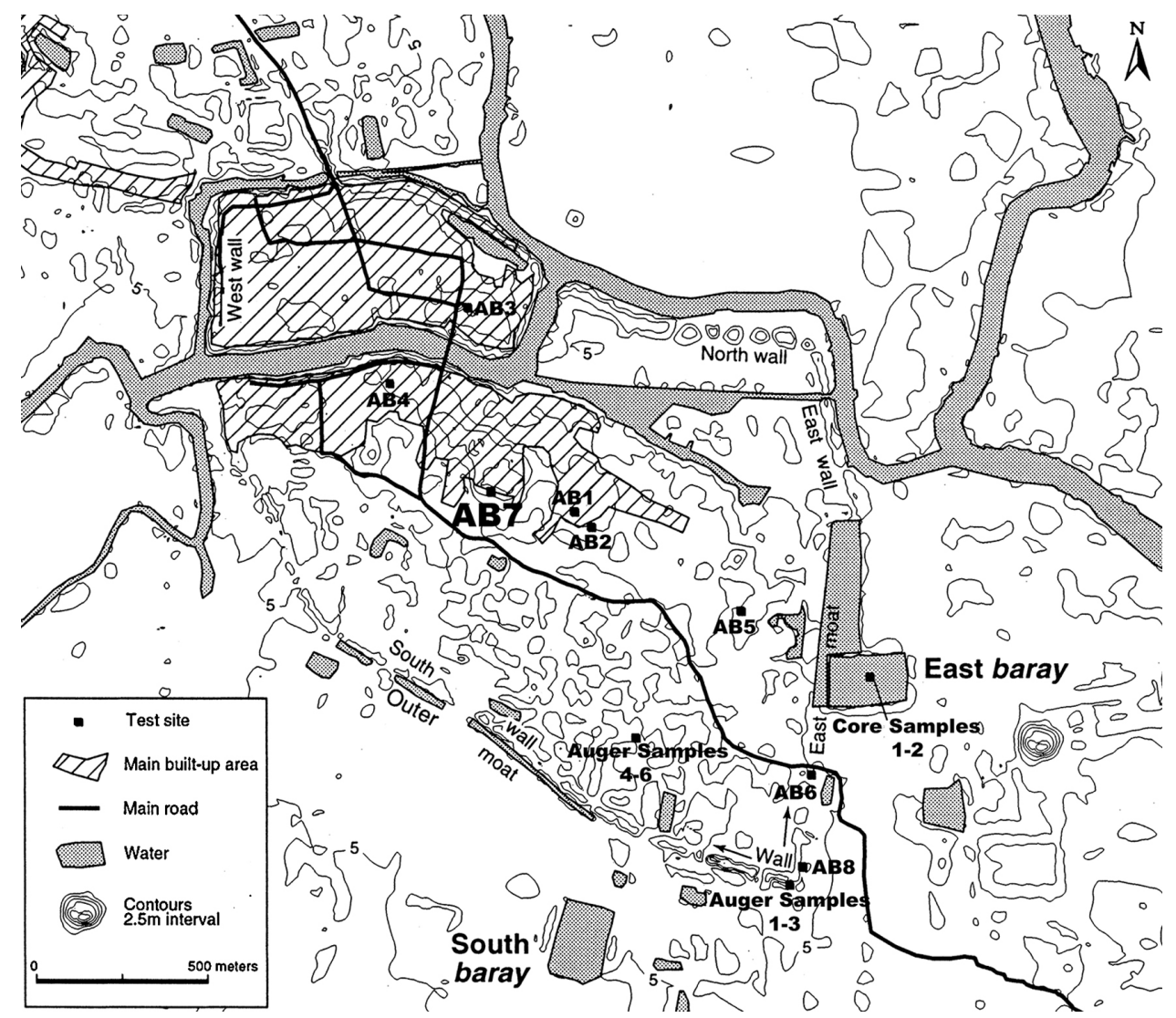

Fig. 3. Contour map of Angkor Borei showing excavation units AB1 through AB8. AB7 is the Vat Komnou cemetery unit. (Modified from Bishop et al. 2003.)

Miriam Stark and colleagues as part of LOMAP (Stark 2001b) (Fig. 3). Human skeletal remains were recovered from excavation unit $\mathrm{AB} 7$, a $5 \mathrm{~m} \times 2 \mathrm{~m}$ unit near the edge of a cemetery mound at Vat Komnou (Fig. 4). A total of 111 individuals were sorted from 57 burial features and analyzed for health indicators, including fertility estimates, stature, dental enamel hypoplasias, oral-dental pathologies, infectious disease, porotic hyperostosis (osteoporosis) of the cranial vault, cribra orbitalia, trauma, and degenerative joint disease (DJD) (Ikehara-Quebral 2010, 2012; Pietrusewsky and Ikehara-Quebral 2006) (Table 2).

Long-term use of the cemetery is suggested by the depth of the stratified burial deposits, the disturbance of presumably long-forgotten individuals during the later interment of others, and the partial mineralization of some of the skeletal elements. Despite site disturbance, the presence of 33 primary burials, most interred in the same orientation (with head pointing southwest), suggests the excavated portion (approximately 0.03 percent of the mound) was part of a designated communal burial area. The Vat Komnou mortuary assemblage includes beads, ceramics, and faunal remains (Bong 2003; Carter 2012, 2015, 2016; Dussubieux and Gratuze 2003; Fehrenbach 2009; Hammerle 2004; Stark 2006b; Voeun and von den Driesch 2004). 


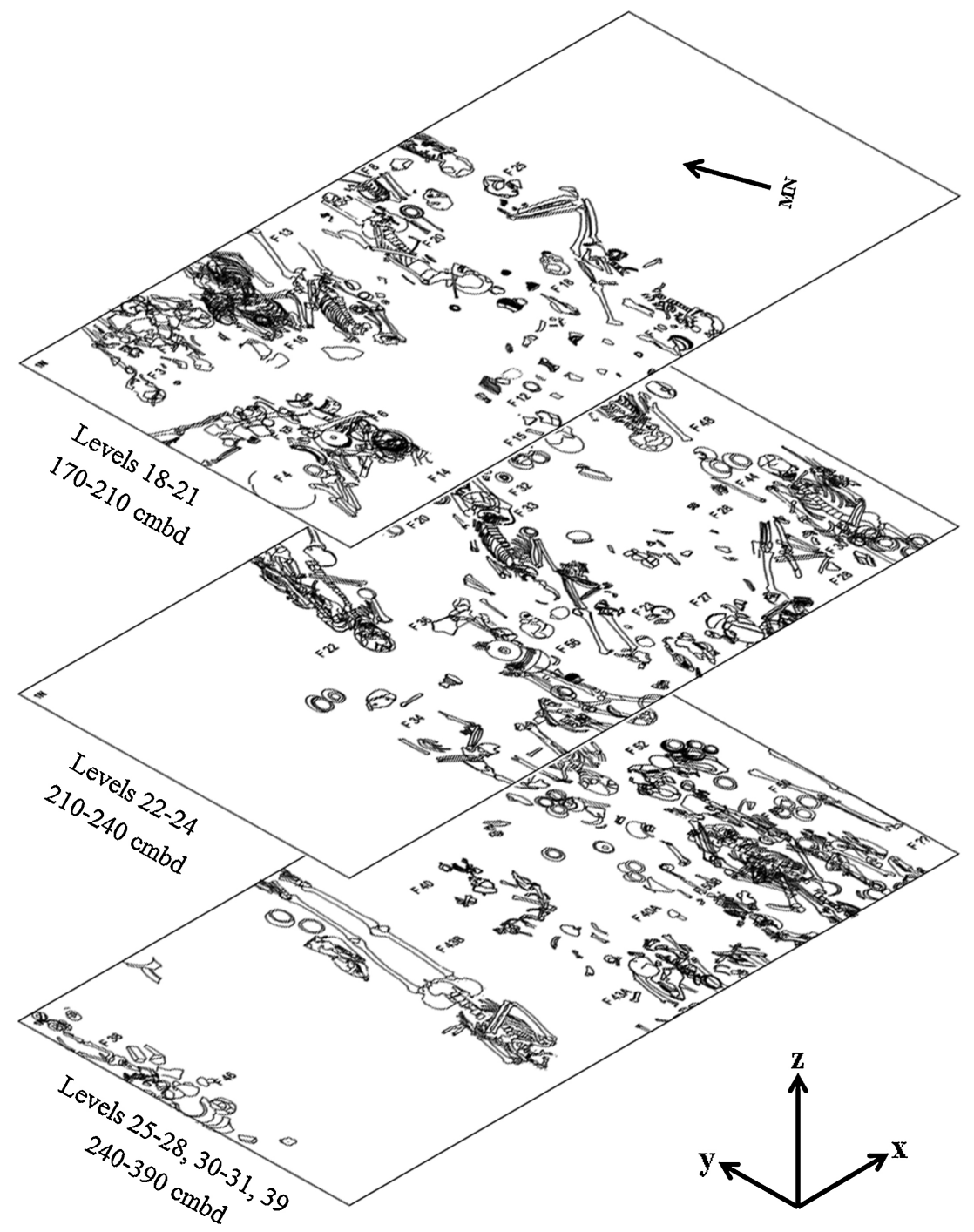

Fig. 4. An oblique multi-level view of the $2 \mathrm{~m} \times 5 \mathrm{~m}$ excavation unit (AB7) showing the Vat Komnou burials. Individual plan views digitized by David Ansberry are collapsed and transformed here to show the depth and density of burials. Top and middle layers: 200 B.C.E. -200 C.E. Bottom layer: 400-200 B.C.E.

\section{Ceramics}

LOMAP excavations from 1996 to 2000 produced approximately 157,000 ceramic sherds from Angkor Borei and 151 reconstructable mortuary ceramics from Vat Komnou (Bong 2003). Ceramic evidence at Angkor Borei suggests broad interactional networks with populations across the Mekong Delta intensified over time, while complex, community-based, local manufacturing traditions persisted (Fehrenbach 2009:157). Preliminary analyses of the distribution of ceramic vessels clearly associated with primary burials indicate that pots were buried at the feet or near the lower legs of 
Table 2. Age-Sex Distribution of Burials from Vat Komnou, Angkor Borei, Cambodia

\begin{tabular}{|c|c|c|c|c|}
\hline AGE CATEGORY (YEARS) ${ }^{a}$ & $\mathrm{MALE}^{\mathrm{b}}$ & FEMALE $^{c}$ & ?SEX ${ }^{\mathrm{d}}$ & TOTAL \\
\hline Fetal & 0 & 0 & 0 & 0 \\
\hline N.B. -0.9 & 0 & 0 & 3 & 3 \\
\hline $1-2.9$ & 0 & 2 & 4 & 6 \\
\hline $3-4.9$ & 0 & 2 & 1 & 3 \\
\hline $5-9.9$ & 4 & 2 & 6 & 12 \\
\hline $10-14.9$ & 3 & 1 & 3 & 7 \\
\hline 15-19.9 & 3 & 3 & 1 & 7 \\
\hline Subadults $<15$ total & 7 & 7 & 17 & 31 \\
\hline Subadults $<20$ total & 10 & 10 & 18 & 38 \\
\hline $20-24.9$ & 2 & 4 & 0 & 6 \\
\hline $25-29.9$ & 1 & 1 & 0 & 2 \\
\hline $30-34.9$ & 5 & 3 & 0 & 8 \\
\hline Young adult (20-35) & 13 & 5 & 1 & 19 \\
\hline $35-39.9$ & 1 & 0 & 0 & 1 \\
\hline $40-44.9$ & 4 & 1 & 0 & 5 \\
\hline $45-49.9$ & 1 & 0 & 0 & 1 \\
\hline Middle-aged (35-50) & 2 & 4 & 0 & 6 \\
\hline $50+$ & 1 & 0 & 0 & 1 \\
\hline Adult $(\geq 20)$ & 18 & 5 & 1 & 24 \\
\hline Individuals $\geq 15$ total & 51 & 26 & 3 & 80 \\
\hline Adults $\geq 20$ total & 48 & 23 & 2 & 73 \\
\hline Total & $58(52.3 \%)$ & $33(29.7 \%)$ & $20(18.0 \%)$ & 111 \\
\hline
\end{tabular}

${ }^{\text {a }}$ For individuals with a 10 -year age range, median age is used to place in an age category.

${ }^{\mathrm{b}}$ Male and ?male (probable male) have been combined in male frequencies.

${ }^{\mathrm{c}}$ Female and ?female (probable female) have been combined in female frequencies.

${ }^{\mathrm{d}}$ Sex undetermined.

the deceased; they were found in equal numbers buried with adult males and females, and also found with subadults (Ikehara-Quebral et al. 2013).

\section{Fauna}

Over 32,000 faunal fragments recovered archaeologically from Angkor Borei were examined by Voeun Vuthy and William Belcher, although over 14,000 fragments were unidentifiable beyond class level (i.e., as mammalian, etc.). All major taxa of local fauna are represented, including both wild resources as well as domesticates (Table 3). The dominant mammal in the assemblage is domesticated pig (Sus scrofa), primarily juvenile to young adult. Most of the pig remains were recovered from burial feature contexts and fill, although the context suggests these were not always clearly associated with primary burials. Sus scrofa comprises 30.4 percent of the total number of identified specimens (NISP) in the Angkor Borei faunal assemblage and nearly 80 percent of identified mammal remains. This suggests a reliance on domesticated pigs for subsistence; however, the importance of pigs as a form of symbolic offering is evident in the presence of pig heads 
Table 3. Identified Non-human Taxa from the Angkor Borei Site, Excavation Seasons 1996, 1999, AND 2000

\begin{tabular}{|c|c|c|c|}
\hline FAMILY & GENUS/SPECIES & ENGLISH COMMON NAME & NISP $^{a}$ \\
\hline \multicolumn{4}{|l|}{ Mammals } \\
\hline Suidae & Sus scrofa & Pig & 5304 \\
\hline Bovidae & Bos gaur & Gaur (wild cattle) & 57 \\
\hline Bovidae & Bos species & Cattle & 277 \\
\hline Bovidae & Nemorhaedus sumatraensis & Serow & 1 \\
\hline Bovidae & Bubalus arnee & Wild water buffalo & 79 \\
\hline Cervidae & Muntiacus muntjak & Muntjac deer & 191 \\
\hline Cervidae & Cervus unicolor & Sambar deer & 118 \\
\hline Cervidae & Tragulus napu & Mouse deer & 4 \\
\hline Cervidae & Axis porcinus & Hog deer & 81 \\
\hline Muridae & Rattus argentiventer & Rice rat & 361 \\
\hline Felidae & Prionailurus viverinus & Fishing cat & 7 \\
\hline Felidae & Panthera species & Tiger & 6 \\
\hline Viverridae & Paradoxurus species & Civet & 97 \\
\hline Sciuridae & Callosciurus species & Squirrel & 39 \\
\hline Canidae & Canis aureus & Asiatic jackal & 34 \\
\hline Leporidae & Nesolagus species & Rabbit & 5 \\
\hline Vespertilionidae & Corynorhinus species & Bat & 53 \\
\hline Elephentidae & Elephas maximus & Elephant & 2 \\
\hline Total mammals & & & 6716 \\
\hline \multicolumn{4}{|l|}{ Birds } \\
\hline Phasianidae & Gallus gallus & Chicken & 139 \\
\hline Ardeidae & Ardea species & Great egret & 25 \\
\hline Ardeidae & Ardeola bacchus & Chinese pond heron & 9 \\
\hline Rallidae & Amaurornis phoenicurus & Breasted water hen & 7 \\
\hline Pelecanidae & Pelecanus onocrotalus & Great white pelican & 4 \\
\hline Phasianidae & Pavo species & Peacock & 2 \\
\hline Passeridae & Carpospiza cf. & Sparrow & 2 \\
\hline Total birds & & & 188 \\
\hline \multicolumn{4}{|c|}{ Chondrichthyes (cartilaginous fishes) } \\
\hline Carcharhinidae & Rhizoprionodon acutus & Milk shark & 8 \\
\hline Total chondricht & & & 8 \\
\hline \multicolumn{4}{|c|}{ Osteichthyes (bony fishes) } \\
\hline Channidae & Channa striata & Snakehead murrel & 3423 \\
\hline Channidae & Channa micropeltes & Giant snakehead & 583 \\
\hline Clariidae & Clarias meladerma & Black skin catfish & 639 \\
\hline Bagridae & Mystus nemurus & Asian red rail catfish & 162 \\
\hline Bagridae & Mystus species cf. wolffi & & 64 \\
\hline Pangasidae & Pangasianodon hypophthalmus & Iridescent shark-catfish & 41 \\
\hline Siluridae & Ompok bimaculatus & Butter catfish & 1 \\
\hline Siluridae & Wallago attu & Wallago & 29 \\
\hline Nandidae & Pristolepis fasciata & Catopra & 14 \\
\hline Belontiidae & Trichogaster trichoperus & Three-spot gourami & 92 \\
\hline
\end{tabular}

(Continued) 
TABLE 3. (Continued)

\begin{tabular}{|c|c|c|c|}
\hline FAMILY & GENUS/SPECIES & ENGLISH COMMON NAME & NISP $^{a}$ \\
\hline Belontiidae & Trichogaster pectoralis & Snakeskin gourami & 13 \\
\hline Anabantidae & Anabas testudineus & Climbing perch & 1996 \\
\hline Cyprinidae & Cyclocheilichthys enoplos & Soldier river barb & 11 \\
\hline Cyprinidae & Cyprenus species & Carp & 18 \\
\hline Cyprinidae & Puntioplites proctozysron & Carp & 9 \\
\hline Sciaenidae & Boesemania microlepis & Small-scale croaker & 7 \\
\hline Schilbeidae & Laides cf. & & 4 \\
\hline Notopteridae & Chatila ornata & Clown feather back & 4 \\
\hline Notopteridae & Notopterus notopterus & Bronze feather back & 3 \\
\hline Centropomidae & Lates calcarifer & Barramundi & 3 \\
\hline Engraulidae & Lycothrissa crocodilus & Sabertooth thryssa & 3 \\
\hline Soleidae & Euryglossa panoides & Flat fish & 1 \\
\hline Cyprinidae & Probarbus jullieni & Seven-line barb & 1 \\
\hline Sybranchidae & Monopterus albus & Swamp eel & 115 \\
\hline Total osteichthyes & & & 7236 \\
\hline \multicolumn{4}{|l|}{ Reptiles and amphibians } \\
\hline Geoemydidae & Malayemys subtrijuga & Rice field terrapin turtle & 2448 \\
\hline Geoemydidae & Hieremys annandalii & Yellow headed temple turtle & 159 \\
\hline Geoemydidae & Batagur baska & River terrapin & 35 \\
\hline Trionychidae & Trionyx cartilaginous & Asiatic soft-shell & 30 \\
\hline Testudinidae & Indotestudo enlongata & Elongated tortoise & 10 \\
\hline Colubridae & Ptyas cf. & Colubrid snakes & 4 \\
\hline Crocodylidae & Crocodylus siamensis & Crocodile & 4 \\
\hline Ranidae & Rana species & Frog & 2 \\
\hline Total reptiles and amphibians & & & 2692 \\
\hline \multicolumn{4}{|l|}{ Molluscs, shellfish } \\
\hline Ampullariidae & Pomacea bridgesii & Apple snails & 387 \\
\hline Ampullariidae & Pila ampullaceal & & 117 \\
\hline Unionidae & Alasmidonta species & Freshwater big clam & 41 \\
\hline Turbinidae & Turbo petholata & Snail shell & 30 \\
\hline Corbiculidae & Corbicula fluminea & Clams & 27 \\
\hline Veneridae & Venus verrucosa & Saltwater clams & 8 \\
\hline Thiaridae & Melanoides tuberculata & Freshwater snail & 6 \\
\hline Cardiidae & Tridacna gigas & Giant clam & 2 \\
\hline Turbinidae & Arca granulosa & Cockle ark shell & 1 \\
\hline Margaritiferidae & Margaritifera margaritifera & Freshwater mussel & 1 \\
\hline Cypraeidae & Cypraea species & Cowrie shell & 1 \\
\hline Total molluscs, shellfish & & & 621 \\
\hline Total identified fauna & & & 17,461 \\
\hline Unidentified & Unidentified & Unidentified & 14,567 \\
\hline $\begin{array}{l}\text { Total examined } \\
\text { (identified and unidentified) }\end{array}$ & & & 32,028 \\
\hline
\end{tabular}

${ }^{a}$ Number of identified specimens. 
as possible mortuary offerings in at least six of the 33 primary burials (Fig. 5). This mortuary practice is common in comparative Protohistoric/Iron Age samples, though not seen in modern Cambodia (pers. comm., Piphal Heng, 24 March 2013). Other domesticated species include cattle (cf. Bos taurus and Bos indicus) and chicken (Gallus gallus domesticus). Wild animals include elephant, various deer, tiger, wild water buffalo (Bubalus arnee), wild cattle (Bos gaur), and crocodile.

Fish, including fresh and brackish water species, represent a large proportion of available protein sources at Angkor Borei, which is consistent with the relatively greater reliance on fish/estuary resources determined by stable isotope analyses of the human skeletal sample (see below). The two dominant fish species are the snakehead murrel (19.6 percent) and the climbing perch (11.4 percent), calculated as proportions of the total faunal NISP. Snakehead murrel and climbing perch make up 47.3 percent and 27.6 percent, respectively, of the bony fishes NISP. The importance of fish is underscored by its ritual use as mortuary offerings, including fish in ceramic pots placed with some of the Vat Komnou burials, a practice also found at Phum Snay (O'Reilly et al. 2006:202). Snakehead murrel is an important ritual offering throughout South Asia; it is associated with Hinduism and Buddhist traditions that may have influenced these regional Southeast Asian cultures (Belcher 1998:391-394). The faunal remains at Angkor Borei represent a broad-spectrum use of the local environment as well as possible trade materials from a more coastal area. Ongoing analyses of the faunal data aim to discern changes in the local environment over time.

\section{Isotope Ratio Analyses}

Strontium $(\mathrm{Sr})$ isotope ratios measured in tooth enamel can inform patterns of mobility and inter-group migration practices (Bentley 2006; Bentley et al. 2007). The strontium isotope signature is robustly preserved by tooth enamel in particular, even in tropical and subtropical environments (Bentley et al. 2009). Enamel records a snapshot of time (2+ years) during the period of enamel mineralization of the particular tooth sampled. Strontium ratios $\left({ }^{87} \mathrm{Sr} /{ }^{86} \mathrm{Sr}\right)$ are recorded in biological tissues from strontium leached into the biosphere from weathered bedrock. They reflect the mixture of weathered sources into the food chain with negligible fractionation of ${ }^{87} \mathrm{Sr} /{ }^{86} \mathrm{Sr}$ (Bentley 2006). Oxygen isotope ratios $\left(\delta^{18} \mathrm{O}\right)$ reflect body water and ultimately sources of drinking water, underlain by the hydrologic cycle which changes with climate (Sarkar et al. 2016). The $\delta^{18} \mathrm{O}$ in mammalian carbonate essentially depends on the $\delta^{18} \mathrm{O}$ value of drinking water, but the detailed systematics from water sources to mammalian body to skeletal tissues are complex (Bryant et al. 1996; Kohn 1996). Fortunately, due to the averaging of water sources in the body, $\delta^{18} \mathrm{O}$ measured in teeth is typically reflective of geographic origin (Budd et al. 2004).

Stable isotope ratios recorded in bones and teeth can be analyzed to document shifts in diet, assess the relative importance of particular foods in past populations, and may act as a proxy to the local environment (Larsen 2002; Lee-Thorp 2008). Nitrogen isotope ratios $\left(\delta^{15} \mathrm{~N}\right)$ are assumed to record the average dietary protein intake (Lee-Thorp 2008), but they may be affected by farming practices such as manuring (Bogaard et al. 2013). Carbon isotope ratios $\left(\delta^{13} \mathrm{C}\right)$ can be used to assess the average amount of $\mathrm{C}_{3}$ and $\mathrm{C}_{4}$ plant consumption (including animals that consumed $\mathrm{C}_{3}$ and $\mathrm{C}_{4}$ plants) and may also be used to discriminate between marine and terrestrial food sources (Lee-Thorp 2008). $\mathrm{C}_{3}$ plants include all native fruit, nuts, herbs, and vegetables endemic to mainland Southeast Asia, 


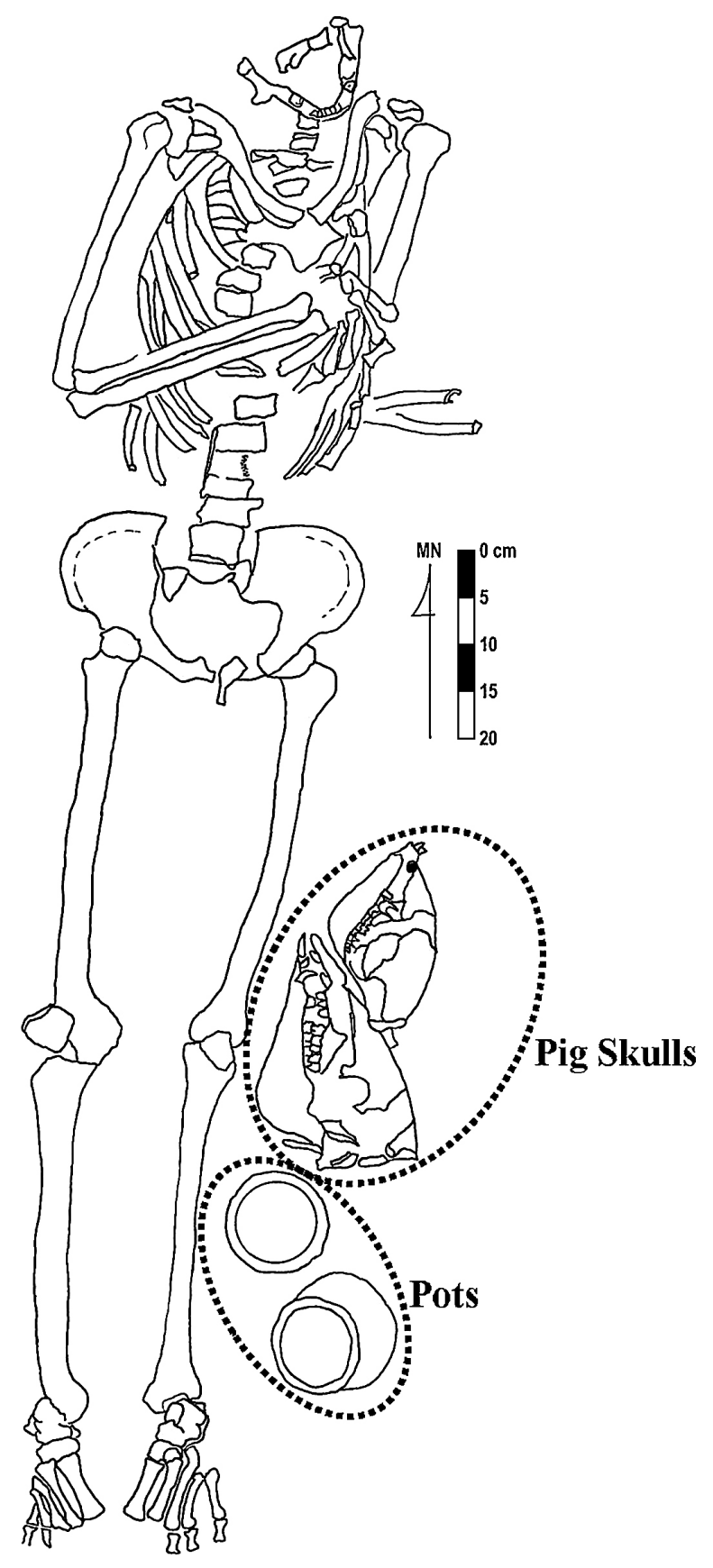

Fig. 5. Pots and pig skulls found with Vat Komnou Burial 43B, a 45-55+ year-old male. Plan view drawn by Miriam Stark and digitized by Matthew Bell. 
including rice. $\mathrm{C}_{4}$ plants, adapted to drier, more arid conditions than $\mathrm{C}_{3}$ plants, include millets, sugarcane, and maize. Data presented below include results from isotope analyses conducted on rib bone and molar tooth enamel sampled from five males and five females recovered from Vat Komnou (Krigbaum et al. 2008) (Table 4).

Isotopic Signatures of Geographic Origin — First, the oxygen $\left(\delta^{18} \mathrm{O}\right)$ vs. strontium $\left({ }^{87} \mathrm{Sr} /{ }^{86} \mathrm{Sr}\right)$ isotope ratios of the Vat Komnou tooth enamel were compared to several well-documented skeletal assemblages from Thailand. When Vat Komnou is compared to strictly Iron Age samples from Ban Non Wat (King et al. 2013; Newton 2014) and Noen U-Loke (Cox et al. 2011), both located in the Upper Mun River Valley, its ${ }^{87} \mathrm{Sr} /{ }^{86} \mathrm{Sr}$ ratios are distinctly different, suggesting little detectable migration between Vat Komnou and the other sites during this period (Fig. 6). Figure 7 depicts an expanded comparison, adding Neolithic and Bronze Age individuals from Ban Non Wat (King et al. 2013), a Bronze Age sample from Ban Lum Khao in the Upper Mun River Valley (Bentley et al. 2009), an inland Neolithic to Early Iron Age sample from Ban Chiang (Bentley et al. 2005), and a Neolithic coastal sample from Khok Phanom Di (Bentley et al. 2007). The samples from the three Mun River Valley sites and Khok Phanom Di display a similar range of ${ }^{87} \mathrm{Sr} /{ }^{86} \mathrm{Sr}$ values, falling between 0.7091 and 0.7118 , and are distinctly different from the two remaining samples (Bentley et al. 2009; Cox et al. 2011; King et al., 2013). The Vat Komnou ${ }^{87} \mathrm{Sr} /{ }^{86} \mathrm{Sr}$ values (0.7083-0.7093 and 0.7109-0.7113) generally fall outside of the range reported for Mun River Valley sites (0.7094 and 0.7118) and Khok Phanom Di (0.7091-0.7100), while the Ban Chiang ratios (0.7106-0.7133) are much higher, indicating little interaction between Ban Chiang and the other groups. While its sample size is small, the mean ${ }^{87} \mathrm{Sr} /{ }^{86} \mathrm{Sr}$ for Vat Komnou of $0.7100 \pm 0.0013$ falls on the tail end of the range of ratios reported for the Mun River Valley sites and Khok Phanom Di.

Two distinct clusters at Vat Komnou suggest two geographic origins: one presumed non-local group with elevated ${ }^{87} \mathrm{Sr} /{ }^{86} \mathrm{Sr}$ ratios that emigrated from the north sometime after their permanent second molars developed $\left({ }^{87} \mathrm{Sr} /{ }^{86} \mathrm{Sr}\right.$ values broadly similar to those from Ban Chiang) and one presumed local group (Krigbaum et al. 2008). Burial 36 , a male, appears to have emigrated from northern uplands (possibly Khorat Plateau) based on a water source signature $\left(\delta^{18} \mathrm{O}_{\mathrm{PDB}}=-2.6\right)$ that is distinctly different from the range of male $(-3.8$ to -5.6$)$ and female $(-3.4$ to -5.8$)$ signatures observed in the other Vat Komnou individuals.

The burials that form the two isotope clusters were not spatially distinct from the other burials in the cemetery, but closer examination revealed differences in possible social status markers (Ikehara-Quebral 2010:43-44). While most of the 33 primary burials were ritually buried with their head pointing southwest (including immigrant Burials 5, 22, 36), two notable exceptions belong to the first cluster, the non-local group. Burial 44, a 35-45-year-old female, was oriented with her head pointing northeast. She was interred with the most elaborate assortment of beads associated with a primary burial at Vat Komnou: 13 gold, 1 garnet, 1 Carnelian, and numerous glass beads. Burial 17, a 30-35year-old male, was interred with his head pointing northwest. The difference in burial orientation was perhaps meant to signify a different homeland or social status.

The second isotope cluster, discerned as the local group, includes three Vat Komnou individuals that display purposeful dental filing of the anterior teeth (described below). Burial 36, considered non-local by isotope analysis, also displays dental filing. The very small number of Vat Komnou individuals with filed teeth (two males and two females, 


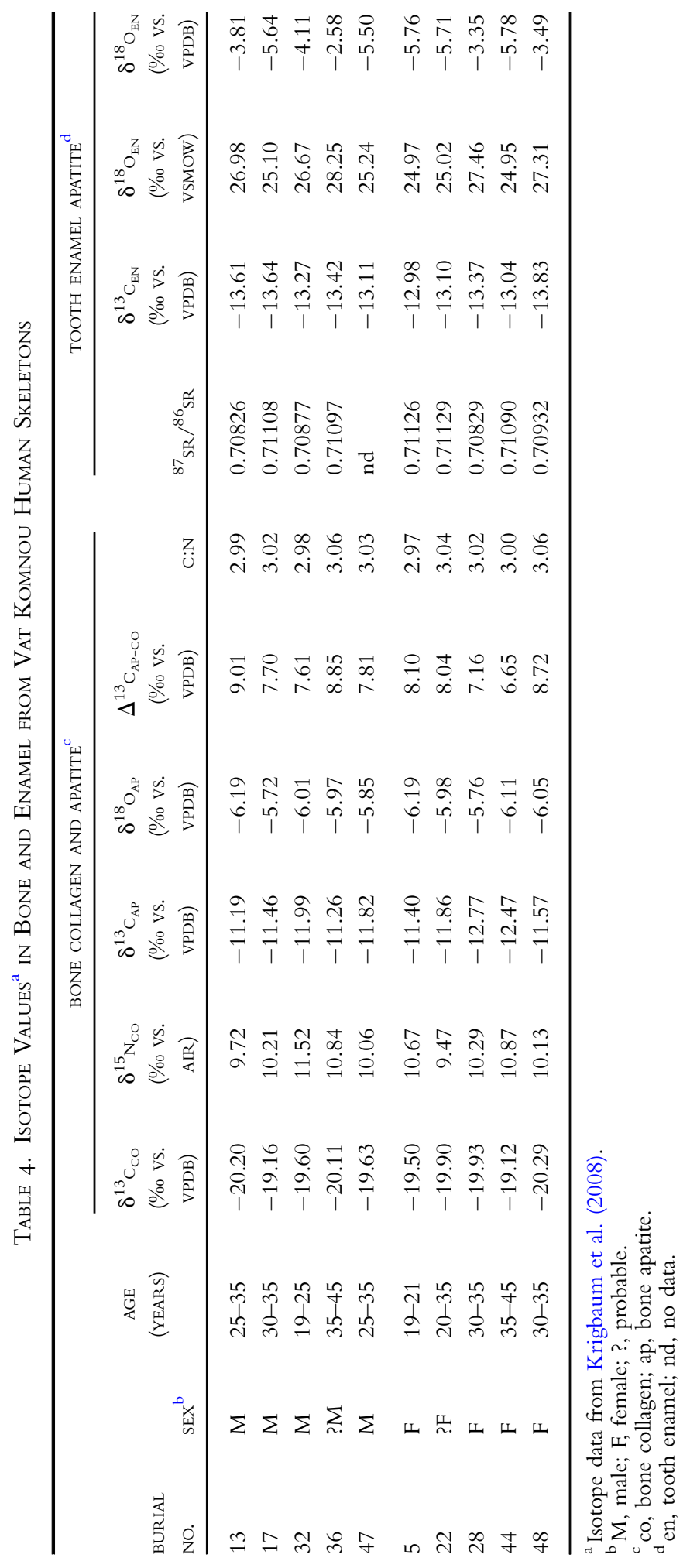




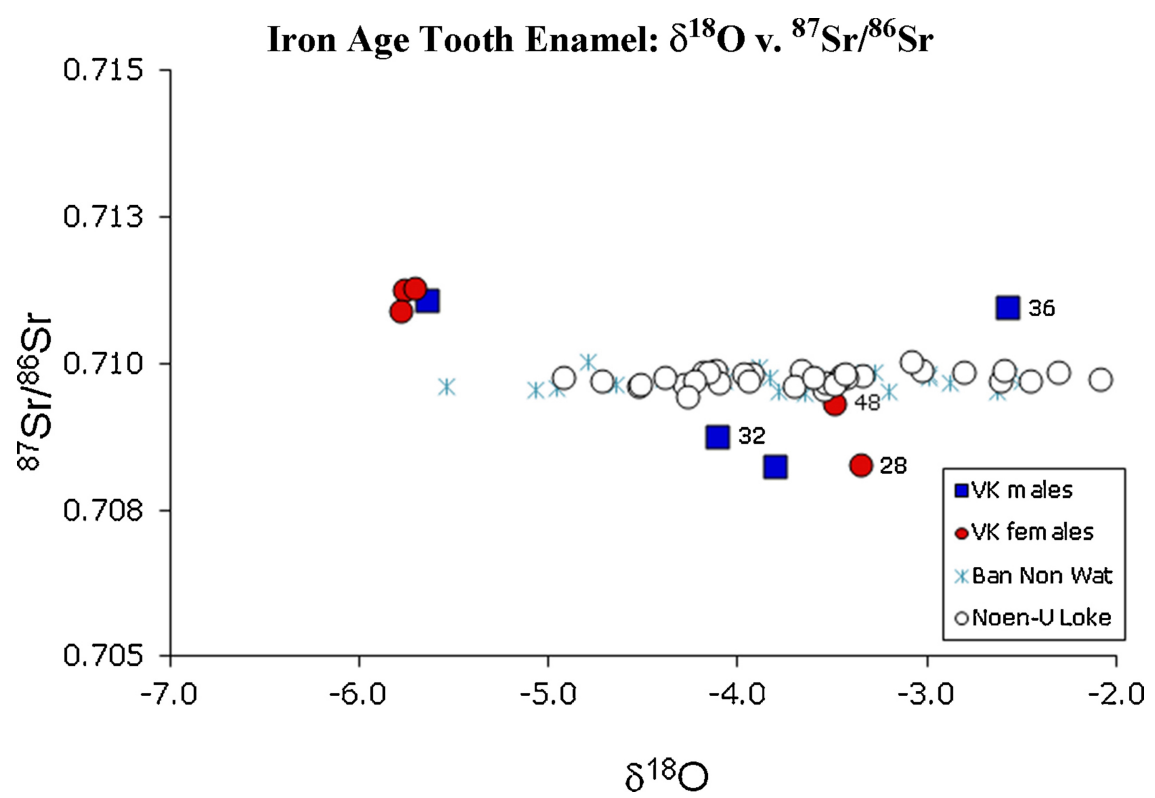

Fig. 6. Oxygen versus strontium isotope ratios of tooth enamel sampled from Vat Komnou (VK) and Iron Ages sites Ban Non Wat and Noen U-Loke. Four VK individuals $(28,32,36,48)$ with dental filing are labeled.

Southeast Asia Tooth Enamel: $\delta^{18} \mathrm{O}$ v. ${ }^{87} \mathrm{Sr} /{ }^{86} \mathrm{Sr}$

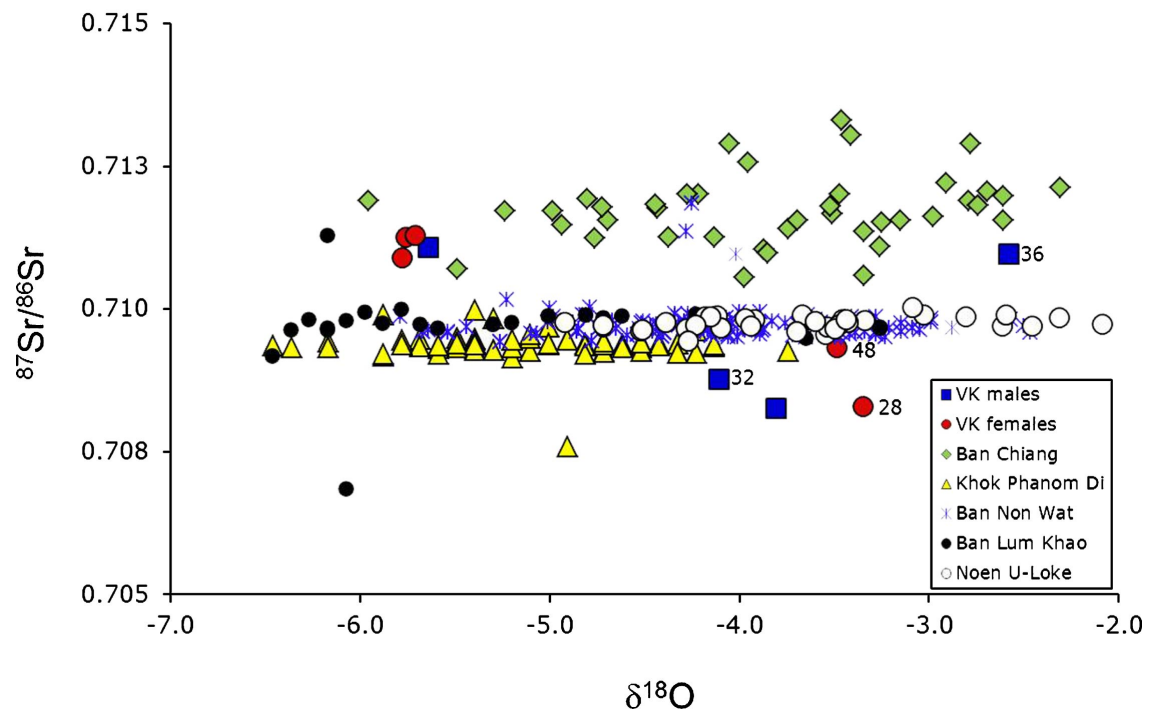

Fig. 7. Oxygen versus strontium isotope ratios of tooth enamel sampled from Vat Komnou (VK) and five skeletal assemblages from Thailand. Four VK individuals $(28,32,36,48)$ with dental filing are labeled. 
labeled with burial numbers in Figs. 6,7) suggests a shared social status or group membership which includes Burial 36.

Isotopic Signatures and Diet - Next, the carbon $\left(\delta^{13} \mathrm{C}\right)$ versus nitrogen $\left(\delta^{15} \mathrm{~N}\right)$ isotope ratios of the Vat Komnou bone collagen were compared to published data from Ban Chiang (King and Norr 2006) and two Neolithic samples from China: Jiahu, south of the Yellow River and associated with rice agriculture (Hu et al. 2006); and several millet-associated sites in northern China along the Yellow/Wei River drainage (Pechenkina et al. 2005) (Fig. 8). At Ban Chiang, previous isotopic studies suggested a broad spectrum economy at least until the end of the Bronze Period (Bentley et al. 2005) and a diet consistent with wet-rice agriculture and domesticated animals (King and Norr 2006). Based on analyses of both bone collagen $\delta^{13} \mathrm{C}$ and $\delta^{15} \mathrm{~N}$, bone apatite $\delta^{13} \mathrm{C}$, and $\Delta^{13} \mathrm{C}$ bone collagen-apatite spacing, Krigbaum and colleagues (2008) suggested the Vat Komnou inhabitants consumed relatively less terrestrial protein, but with a relatively greater reliance on fish and estuarine/riverine protein compared to the other groups, and little or no evidence of $\mathrm{a}_{4}$ diet such as the sample population from the Yellow/Wei river valleys. A diet dominated by $\mathrm{C}_{3}$ food resources, which would include rice, is suggested by $\delta^{13} \mathrm{C}$ between about $-20.5 \%$ and $-18 \%$ in bone collagen at Vat Komnou, supplemented by some terrestrial protein and substantial riverine/ estuarine protein (Fig. 8). This is consistent with the Southeast Asia archaeological record, which depicts rice cultivation as a mainstay of the subsistence economy at Iron Age sites such as Noen U-Loke (Higham 2014:247). To further illuminate Vat Komnou dietary and cultural practices based on stable isotope ratios, additional bone and tooth samples, including faunal remains, are being analyzed.

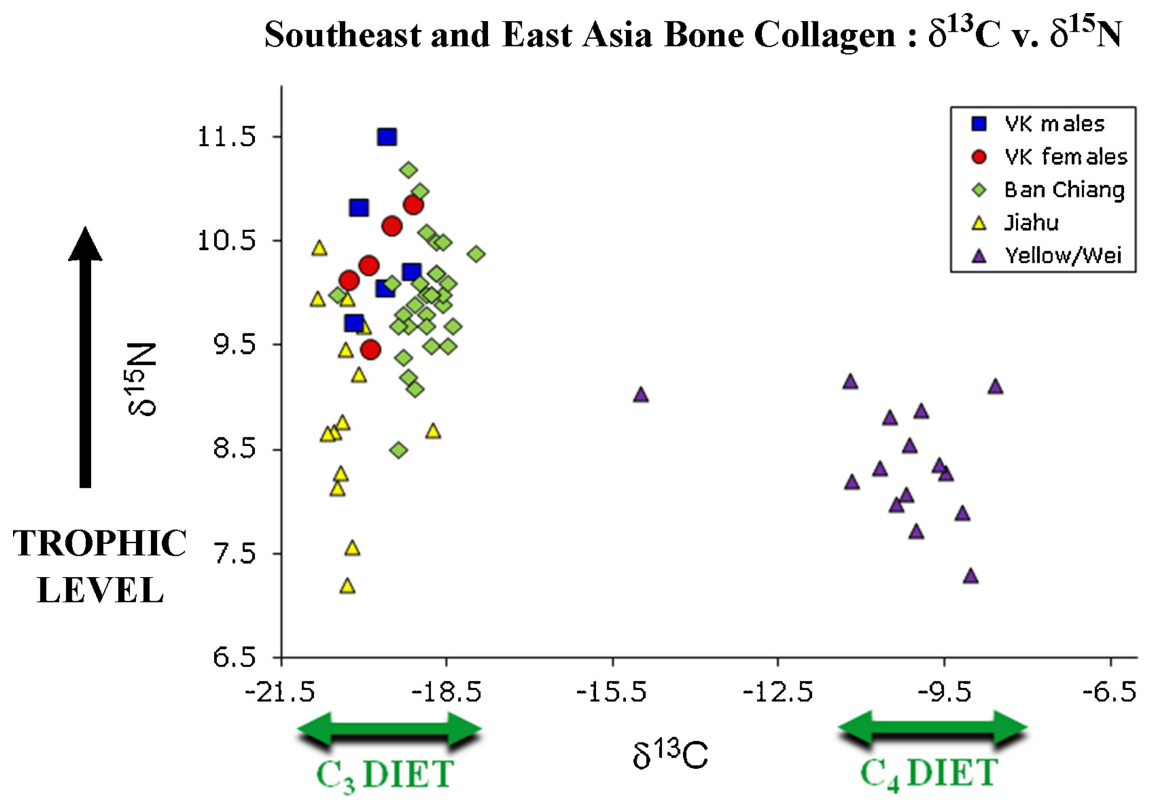

Fig. 8. Carbon versus nitrogen isotope ratios of bone collagen sampled from Vat Komnou (VK), Ban Chiang, and two Neolithic sites from northern China. 


\section{Human Skeletal and Dental Remains}

Preservation of the Vat Komnou human skeletons ranges from very poor to excellent, with the majority in good to fair condition, while completeness ranges from a few fragments to nearly complete skeletons. Life expectancy at birth for individuals is nearly 23 years using an abridged life table or 25.3 years based on the estimated median age-at-death of each individual (Ikehara-Quebral 2010). The total fertility rate is high, estimated at seven children born to each woman reaching 45 years. Subadults comprise about one-third of the burial sample and nearly half of the adults (individuals 20 years or older) died during young adulthood. The adult ( $\geq 15$ years) male-to-female ratio of $2: 1$ is significantly different from the expected normal distribution of $1: 1$ in sites worldwide $\left(\chi^{2}=8.117, d f=1, p=0.0044, N=77\right) .{ }^{1}$ This difference may be attributed to differential mortuary practices, immigration of male laborers, or the out-migration of females. Estimated adult stature of the Vat Komnou sample is $165.3 \mathrm{~cm}$ in males and $154.8 \mathrm{~cm}$ in females (Ikehara-Quebral 2010), comparable to other pre-modern Southeast Asia samples, but $4 \mathrm{~cm}$ taller than modern inhabitants of Cambodia (Olivier 1968; Sangvichien et al. 1985, n.d.).

The incidence of infectious disease at Vat Komnou is very low, affecting 4.5 percent (5/111) of the individuals, and only affecting males (four adults and one adolescent). All cases represent chronic infectious disease, including possible treponemal infection (Ikehara-Quebral 2010:149-150). Evidence of acute infectious disease, such as the flu or weanling diarrhea, would not be observable in the skeleton. In ancient human populations, generally "half of the individuals born died during infancy or childhood" with infectious disease being the major cause of death (Ortner and Putschar 1981:104). The high fertility rate at Vat Komnou indicates childhood mortality was high, but the cause of death is difficult to determine. The absence of pathological changes in most of the skeletons suggests acute infectious disease as a plausible cause of death given the easy accessibility of Vat Komnou via waterways and frequent person-to-person contact as a result of increased trade traffic and interaction in a regional center that was an important political asset in a maritime trade economy (Ikehara-Quebral 2010). In Vietnam, an increase in infectious disease from the Neolithic/Pre-Metal Period (one individual affected) to the Metal Period (as much as 10.9 percent) is attributed to multiple factors, including changes in land use/cultivation, dietary changes, increased pathogen loads, exposure to new disease vectors, massive population movement into the region (including the Han Chinese military campaigns at the terminal Bronze Age), increased population density along with decreasing levels of sanitation, and recent re-location to the region with a less locally-adapted immune system (Oxenham et al. 2005; Oxenham et al. 2006). These factors also likely contributed to the health status of the ancient inhabitants of Vat Komnou and other groups from Southeast Asia, including extensive inter-community trade in the late Iron Age (Newton 2014: 169-171).

Evidence of traumatic injury in the Vat Komnou sample is fairly low, occurring in 13.5 percent $(15 / 111)$ of the individuals, with the risk of injury equal in males and females, and absent in subadults younger than 15 years (Ikehara-Quebral 2010). There are no signs of injuries from warfare or violence. Males are relatively more affected than females by trauma to the neck/throat, wrist, ankle, and foot, while females exhibit more trauma in the hip region (ischiopubic ramus) and lower back. Crushing trauma and shoveler's fractures in the neck in males and Schmorl's nodes and stress fractures in 
the lower back in females can be plausibly attributed to repetitive or strenuous labor activities rather than accidental trauma. Although sex differences per anatomical region cannot be tested for significance due to small sample size, a sexual division of labor is further suggested by DJD frequencies (discussed below). While agricultural productivity in the Mekong Delta was likely high during the Protohistoric/Iron Age Period, there is no evidence of a laborer population at Vat Komnou, given the low incidence of trauma and very little advanced degenerative disease. Low rates of dental disease, linear enamel hypoplasia, trauma, and chronic infectious disease characterize this sample (Ikehara-Quebral 2010).

\section{BIOCULTURAL PRACTICES}

DJD patterns, cultural dental modifications, and indicators of oral-dental health at Vat Komnou and eight neighboring Protohistoric/Iron Age sites are presented to illustrate how biocultural practices may have affected health (Table 5). The Phum Snay and Phum Sophy skeletal series were derived from both excavated material and large ossuary collections (the result of modern looting) (Domett et al. 2013:274). The dental data for some of the comparative samples were not easily accessible, not published in English, not reported in detail, or not consistently quantified for inter-site comparisons, but whenever possible they are included in this study because of the paucity of available Protohistoric/Iron Age data from Cambodia and Vietnam.

\section{Degenerative Joint Disease}

The patterning of DJD, the progressive biomechanical "wear and tear" of the articulating joint surfaces of bones, can be used as an indicator of differential workloads, occupational differences between groups, or a sexual division of labor, even if the stress-inducing activity is not identifiable. In modern populations, DJD appears to be generally more common in females than males, but studies suggest the opposite holds true in prehistoric populations (Machicek and Beach 2013:254). DJD was analyzed by "functional unit" to look for patterns in manifestations of physiological stress (following Douglas 1996). For example, the individual articular surfaces of the scapula, clavicle, and humeral head were summed to represent the shoulder unit. Only adults greater than 20 years of age are included in this discussion. Degenerative changes in the infracranial skeleton were systematically recorded using a scale of none, slight, moderate, or marked degrees of osteoarthritic lipping and degeneration (after Brothwell 1981). Osteoarthritis was scored in the articular facets of the appendicular skeleton and vertebrae; osteoporosis and osteophytic lipping of the vertebral endplates were also recorded. Eburnated and fused joint surfaces were described and documented (following Rogers et al. 1987). Suspected cases of traumatic osteoarthritis, i.e., accelerated degeneration due to trauma rather than normal wear and tear, were excluded. Since relatively few moderate and marked scores were observed, Fisher's Exact Test (FET) was performed on the male-female distribution of absence versus presence (i.e., any expression of DJD). All FET statistics in this paper were calculated with a significance level of $\alpha=0.10$ (two-tailed). For chi-square $\left(\chi^{2}\right)$ tests, a two-by-two contingency table was used, with degrees of freedom $(d f)$ equal to 1 , and Yates' continuity correction factor. 


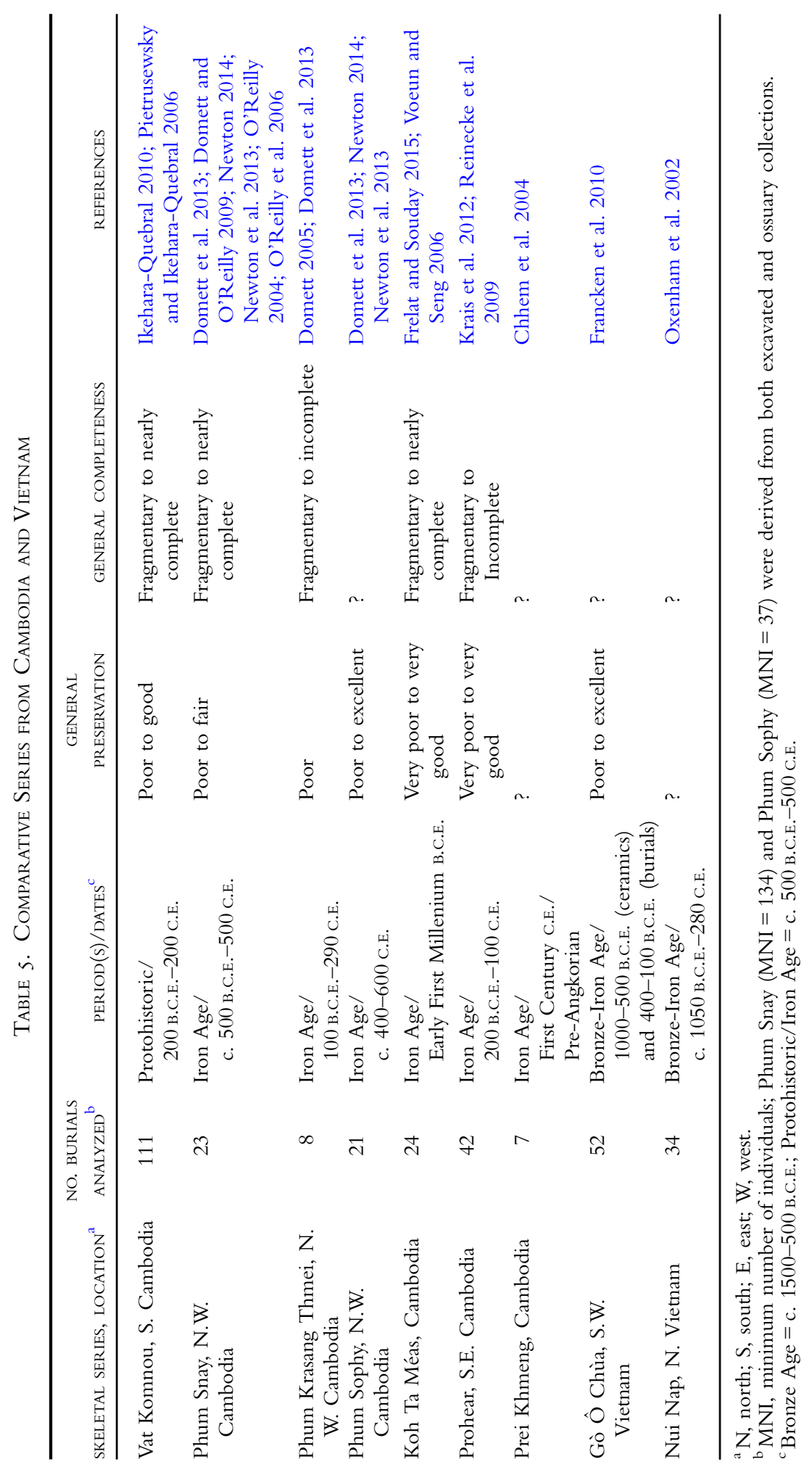


Very little advanced DJD occurs in the adult appendicular and axial skeletons from Vat Komnou, perhaps due to the high number of young adults in the sample. When analyzed by age, appendicular DJD shows no significant differences between males and females. In the axial skeleton, young adult (20-35 years) females have significantly higher rates of osteoarthritis in the sacroiliac joint, osteophytic lipping of the thoracic endplates, and osteophytic lipping of the combined vertebral endplates than males (Table 6). In middle-aged adults (35-50 years), males have significantly higher rates of osteophytic lipping of the cervical endplates, and osteoarthritis of the articular facets in the cervical, thoracic, and combined vertebrae, while females have a significantly higher rate of osteophytic lipping in the lumbar endplates (Table 7). Analyzing sex differences by functional unit, a significantly higher rate of DJD of any degree occurs in males in the shoulder, ankle, and foot regions and in females in the sacroiliac joint (Table 8 ). In the neck region, osteoarthritis of the articulating facets of the first and

Table 6. Degenerative Joint Disease (DJD) a in Vat Komnou Young Adult Vertebrae and Statistical Tests

\begin{tabular}{|c|c|c|c|c|c|}
\hline \multirow{2}{*}{$\begin{array}{l}\text { YOUNG ADULTS (20-35 YEARS) } \\
\text { ARTICULAR SURFACE }^{\mathrm{b}}\end{array}$} & \multicolumn{2}{|c|}{$\operatorname{MALE}(\mathrm{M})$} & \multicolumn{2}{|c|}{ FEMALE (F) } & \multirow{2}{*}{$\begin{array}{c}\text { M VS. F } \\
\text { FET }^{\mathrm{d}}{ }_{\text {PROBABILITY }}\end{array}$} \\
\hline & $\mathrm{A} / \mathrm{O}^{\mathrm{c}}$ & $\%$ & $\mathrm{~A} / \mathrm{O}$ & $\%$ & \\
\hline \multicolumn{6}{|l|}{ Occipital-C1 complex osteoarthritis } \\
\hline Occiput-C1 articulation & $0 / 1$ & 0.0 & $1 / 8$ & 12.5 & $p=1.0000$ \\
\hline Inferior C1-Superior C2 articular facets & $0 / 2$ & 0.0 & $0 / 8$ & 0.0 & $p=1.0000$ \\
\hline C1-Dens articulation & $0 / 3$ & 0.0 & $0 / 5$ & 0.0 & $p=1.0000$ \\
\hline \multicolumn{6}{|l|}{ Cervical vertebrae (Inferior C2 to Superior T1) } \\
\hline Osteoporosis of endplates & $0 / 16$ & 0.0 & $0 / 17$ & 0.0 & $p=1.0000$ \\
\hline Osteophytosis of endplates & $0 / 32$ & 0.0 & $0 / 28$ & 0.0 & $p=1.0000$ \\
\hline Osteoarthritis of articular facets (excluding dens) & $6 / 37$ & 16.2 & $12 / 56$ & 21.4 & $p=0.6007$ \\
\hline \multicolumn{6}{|l|}{ Thoracic vertebrae (Inferior T1 to Superior L1) } \\
\hline Osteoporosis of endplates & $0 / 21$ & 0.0 & $0 / 25$ & 0.0 & $p=1.0000$ \\
\hline Osteophytosis of endplates & $0 / 42$ & 0.0 & $4 / 24$ & 16.7 & $\mathrm{M}<\mathrm{F}, \boldsymbol{p}=\mathbf{0 . 0 1 4 7 ^ { \star }}$ \\
\hline Osteoarthritis of articular facets & $12 / 102$ & 11.8 & $22 / 123$ & 17.9 & $p=0.2621$ \\
\hline \multicolumn{6}{|l|}{ Lumbar vertebrae (Inferior L1 to Superior S1) } \\
\hline Osteoporosis of endplates & $0 / 8$ & 0.0 & $0 / 7$ & 0.0 & $p=1.0000$ \\
\hline Osteophytosis of endplates & $0 / 11$ & 0.0 & $0 / 7$ & 0.0 & $p=1.0000$ \\
\hline Osteoarthritis of articular facets & $9 / 32$ & 28.1 & $8 / 46$ & 17.4 & $p=0.2789$ \\
\hline \multicolumn{6}{|l|}{ Sacroiliac joint } \\
\hline Osteoarthritis if auricular surfaces & $0 / 5$ & 0.0 & $3 / 4$ & 75.0 & $M<F, p=0.0476^{\star}$ \\
\hline \multicolumn{6}{|l|}{ Total Inferior C2 to Superior S1 } \\
\hline Osteoporosis of endplates & $0 / 45$ & 0.0 & $0 / 49$ & 0.0 & $p=1.0000$ \\
\hline Osteophytosis of endplates & $0 / 85$ & 0.0 & $4 / 59$ & 6.8 & $\mathrm{M}<\mathrm{F}, \boldsymbol{p}=\mathbf{0 . 0 2 6 5 ^ { \star }}$ \\
\hline Osteoarthritis of articular facets & $27 / 171$ & 15.8 & $42 / 225$ & 18.7 & $p=0.5048$ \\
\hline
\end{tabular}

${ }^{a}$ Any degree of DJD per element (sides and superior/inferior combined).

${ }^{\mathrm{b}} \mathrm{C}$, cervical; T, thoracic; L, lumbar; S, sacral.

${ }^{\mathrm{c}} \mathrm{O}$, observed; A, affected; frequencies per bone.

${ }^{\mathrm{d}}$ FET, Fisher's Exact Test, two-tailed probabilities reported.

* Distribution is statistically significant at 10 percent level. 
Table 7. Degenerative Joint Disease (DJD) a in Vat Komnou Middle-aged Adult Vertebrae and Statistical Tests

\begin{tabular}{|c|c|c|c|c|c|}
\hline \multirow{2}{*}{$\begin{array}{l}\text { MIDDLE-AGED ADULTS ( } 35-50 \text { YEARS) } \\
\text { ARTICULAR SURFACE }^{\mathrm{b}}\end{array}$} & \multicolumn{2}{|c|}{$\operatorname{MALE}(\mathrm{M})$} & \multicolumn{2}{|c|}{ FEMALE (F) } & \multirow{2}{*}{$\begin{array}{c}\text { M VS. F } \\
\text { FET }^{\mathrm{d}} \stackrel{\text { PROBABILITY }}{ }\end{array}$} \\
\hline & $\mathrm{A} / \mathrm{O}^{\mathrm{c}}$ & $\%$ & $\mathrm{~A} / \mathrm{O}$ & $\%$ & \\
\hline \multicolumn{6}{|l|}{ Occipital-C1 complex osteoarthritis } \\
\hline Occiput-C1 articulation & $1 / 5$ & 20.0 & $2 / 8$ & 25.0 & $p=1.0000$ \\
\hline Inferior C1-Superior C2 articular facets & $1 / 4$ & 25.0 & $0 / 4$ & 0.0 & $p=1.0000$ \\
\hline C1-Dens articulation & $0 / 3$ & 0.0 & $0 / 2$ & 0.0 & $p=1.0000$ \\
\hline \multicolumn{6}{|l|}{ Cervical vertebrae (Inferior C2 to Superior T1) } \\
\hline Osteoporosis of endplates & $5 / 15$ & 33.3 & $0 / 4$ & 0.0 & $p=0.5304$ \\
\hline Osteophytosis of endplates & $10 / 28$ & 35.7 & $0 / 7$ & 0.0 & $M>F, p=0.0835^{\star}$ \\
\hline Osteoarthritis of articular facets (excluding dens) & $13 / 37$ & 35.1 & $0 / 15$ & 0.0 & $M>F, p=0.0106^{\star}$ \\
\hline \multicolumn{6}{|l|}{ Thoracic vertebrae (Inferior T1 to Superior L1) } \\
\hline Osteoporosis of endplates & $0 / 25$ & 0.0 & - & - & $\mathrm{N} / \mathrm{A}$ \\
\hline Osteophytosis of endplates & $8 / 45$ & 17.8 & - & - & $\mathrm{N} / \mathrm{A}$ \\
\hline Osteoarthritis of articular facets & $48 / 72$ & 66.7 & $8 / 35$ & 22.9 & $\mathrm{M}>\mathrm{F}, \boldsymbol{p}<\mathbf{0 . 0 0 0 1 ^ { \star }}$ \\
\hline \multicolumn{6}{|l|}{ Lumbar vertebrae (Inferior L1 to Superior S1) } \\
\hline Osteoporosis of endplates & $0 / 8$ & 0.0 & $0 / 1$ & 0.0 & $p=1.0000$ \\
\hline Osteophytosis of endplates & $0 / 11$ & 0.0 & $1 / 1$ & 100.0 & $\mathrm{M}<\mathrm{F}, \boldsymbol{p}=\mathbf{0 . 0 8 3 3 ^ { \star }}$ \\
\hline Osteoarthritis of articular facets & $15 / 28$ & 53.6 & $3 / 11$ & 27.3 & $p=0.1713$ \\
\hline \multicolumn{6}{|l|}{ Sacroiliac joint } \\
\hline Osteoarthritis of auricular surfaces & $0 / 3$ & 0.0 & $0 / 1$ & 0.0 & $p=1.0000$ \\
\hline \multicolumn{6}{|l|}{ Total Inferior C2 to Superior S1 } \\
\hline Osteoporosis of endplates & $5 / 48$ & 10.4 & $0 / 5$ & 0.0 & $p=1.0000$ \\
\hline Osteophytosis of endplates & $18 / 84$ & 21.4 & $1 / 8$ & 12.5 & $p=1.0000$ \\
\hline Osteoarthritis of articular facets & $76 / 137$ & 55.5 & $11 / 61$ & 18.0 & $\mathrm{M}>\mathrm{F}, \boldsymbol{p}<\mathbf{0 . 0 0 0 1 ^ { \star }}$ \\
\hline
\end{tabular}

${ }^{\mathrm{a}}$ Any degree of DJD per element (sides and superior/inferior combined).

${ }^{\mathrm{b}} \mathrm{C}$, cervical; T, thoracic; L, lumbar; S, sacral.

${ }^{\mathrm{c}} \mathrm{O}$, observed; A, affected; frequencies per bone.

${ }^{\text {d}}$ FET, Fisher's Exact Test, two-tailed probabilities reported; N/A, not applicable.

*Distribution is statistically significant at 10 percent level.

second cervical vertebrae is significantly higher in male vertebrae $(5 / 10$ or 50.0 percent) than female vertebrae (0/12 or 0.0 percent) (FET, $p=0.0096)$. As expected, older individuals display more advanced degenerative changes than younger individuals. Only males attain marked degrees of DJD in the appendicular and vertebral skeleton, indicating participation in more habitual or strenuous activities than females.

These significant differences in the distribution of DJD throughout the appendicular and vertebral skeletons suggest a sexual division of labor that differentially affected the health of males and females beginning in early adulthood. At late Iron Age site Phum Snay, Cambodia, severe degeneration is exhibited in the neck region $(\mathrm{C} 4$, C7) of a middle-aged male, the spine of an 18-22-year-old male (along with Schmorl's nodes), and the right foot of a female (Domett and O'Reilly 2009:72). However, no sex differences were reported due to small sample size. At Iron Age site Gò Ô Chùa, Vietnam, there were no sex differences in DJD rates and the most affected joints were 
Table 8. Appendicular Osteoarthritis in Vat Komnou Adult Skeletons $>20$ Years (Sides Combined) and Statistical Tests

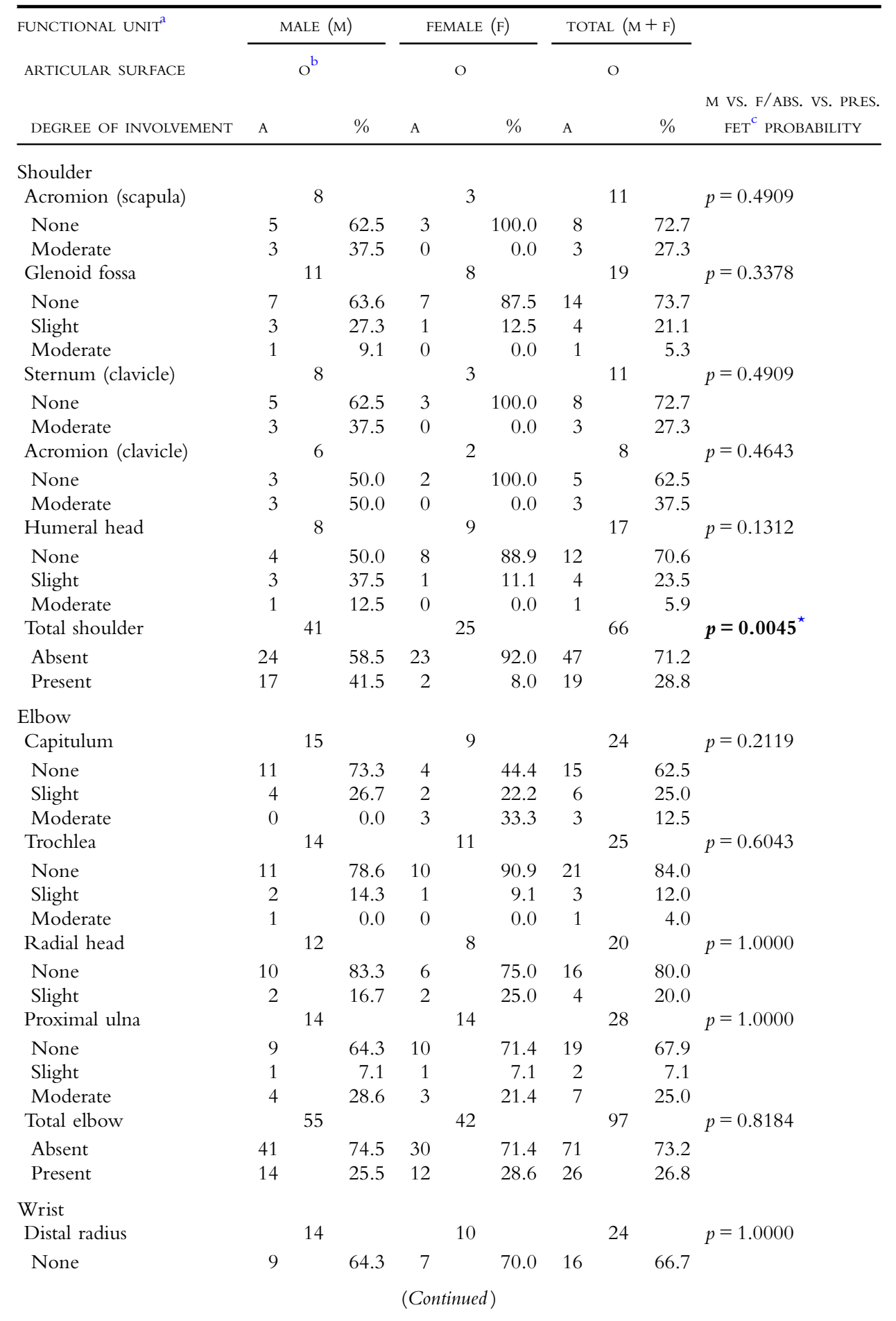


Table 8. (Continued)

\begin{tabular}{|c|c|c|c|c|c|c|c|c|c|}
\hline FUNCTIONAL UNIT $^{a}$ & \multicolumn{3}{|c|}{ MALE (M) } & \multicolumn{2}{|c|}{ FEMALE (F) } & \multicolumn{3}{|c|}{ TOTAL $(M+F)$} & \multirow[b]{3}{*}{$\begin{array}{c}\text { M VS. F/ABS. VS. PRES } \\
\text { FET }^{\mathrm{c}} \text { PROBABILITY }\end{array}$} \\
\hline ARTICULAR SURFACE & & $\mathrm{O}^{\mathrm{b}}$ & & & & & $\mathrm{O}$ & & \\
\hline DEGREE OF INVOLVEMENT & A & & $\%$ & A & $\%$ & A & & $\%$ & \\
\hline Slight & 3 & & 21.4 & 3 & 30.0 & 6 & & 25.0 & \\
\hline Moderate & 2 & & 14.3 & 0 & 0.0 & 2 & & 8.3 & \\
\hline Distal ulna & & 9 & & & & & 14 & & $p=1.0000$ \\
\hline None & 7 & & 77.8 & 4 & 80.0 & 11 & & 78.6 & \\
\hline Slight & 2 & & 22.2 & 1 & 20.0 & 3 & & 21.4 & \\
\hline Total wrist & & 23 & & & & & 38 & & $p=1.0000$ \\
\hline Absent & 16 & & 69.6 & 11 & 73.3 & 27 & & 71.1 & \\
\hline Present & 7 & & 30.4 & 4 & 26.7 & 11 & & 29.0 & \\
\hline \multicolumn{10}{|l|}{ Hand } \\
\hline Carpals & & 16 & & & & & 26 & & $p=1.0000$ \\
\hline None & 14 & & 87.5 & 9 & 90.0 & 23 & & 88.5 & \\
\hline Slight & 2 & & 12.5 & 1 & 10.0 & 3 & & 11.5 & \\
\hline Metacarpals & & 15 & & & & & 30 & & $p=1.0000$ \\
\hline None & 15 & & 100.0 & 15 & 100.0 & 30 & & 100.0 & \\
\hline Hand phalanges & & 18 & & & & & 32 & & $p=1.0000$ \\
\hline None & 17 & & 94.4 & 14 & 100.0 & 31 & & 96.9 & \\
\hline Slight & 1 & & 5.6 & 0 & 0.0 & 1 & & 3.1 & \\
\hline Total hand & & 49 & & & & & 88 & & $p=0.6263$ \\
\hline Absent & 46 & & 93.8 & 38 & 97.4 & 84 & & 95.5 & \\
\hline Present & 3 & & 6.1 & 1 & 2.6 & 4 & & 4.5 & \\
\hline Pelvis & & & & & & & & & $p=0.0769^{\star}$ \\
\hline Sacroiliac & & 10 & & & & & 15 & & \\
\hline None & 9 & & 90.0 & 2 & 40.0 & 11 & & 73.3 & \\
\hline Slight & 1 & & 10.0 & 3 & 60.0 & 4 & & 26.7 & \\
\hline Acetabulum & & 11 & & & & & 17 & & $p=1.0000$ \\
\hline None & 10 & & 90.9 & 6 & 100.0 & 16 & & 94.1 & \\
\hline Slight & 1 & & 9.1 & 0 & 0.0 & 1 & & 5.9 & \\
\hline Femoral head & & 12 & & & & & 17 & & $p=1.0000$ \\
\hline None & 12 & & 100.0 & 5 & 100.0 & 17 & & 100.0 & \\
\hline Total pelvis & & 33 & & & & & 49 & & $p=0.3133$ \\
\hline Absent & 31 & & 93.9 & 13 & 81.3 & 44 & & 89.8 & \\
\hline Present & 2 & & 6.1 & 3 & 18.8 & 5 & & 10.2 & \\
\hline \multicolumn{10}{|l|}{ Knee } \\
\hline Distal femur & & 9 & & & & & 19 & & $p=0.6285$ \\
\hline None & 6 & & 66.7 & 8 & 80.0 & 14 & & 73.7 & \\
\hline Slight & 2 & & 22.2 & 2 & 20.0 & 4 & & 21.1 & \\
\hline Marked & 1 & & 11.1 & 0 & 0.0 & 1 & & 5.3 & \\
\hline Patella & & 6 & & & & & 11 & & $p=1.0000$ \\
\hline None & 5 & & 83.3 & 5 & 100.0 & 10 & & 90.9 & \\
\hline Marked & 1 & & 16.7 & 0 & 0.0 & 1 & & 9.1 & \\
\hline Proximal tibia & & 7 & & & & & 15 & & $p=0.5692$ \\
\hline None & 5 & & 71.4 & 7 & 87.5 & 12 & & 80.0 & \\
\hline Slight & 1 & & 14.3 & 1 & 12.5 & 2 & & 13.3 & \\
\hline Marked & 1 & & 14.3 & 0 & 0.0 & 1 & & 6.7 & \\
\hline
\end{tabular}


TABLE 8. (Continued)

\begin{tabular}{|c|c|c|c|c|c|c|c|c|c|c|}
\hline \multirow{2}{*}{$\begin{array}{l}\text { FUNCTIONAL UNIT }^{a} \\
\text { ARTICULAR SURFACE }\end{array}$} & \multicolumn{3}{|c|}{ MALE (M) } & \multicolumn{3}{|c|}{ FEMALE (F) } & \multicolumn{3}{|c|}{ TOTAL $(M+F)$} & \multirow[b]{3}{*}{$\begin{array}{c}\text { M VS. F/ABS. VS. PRES } \\
\text { FET }^{\mathrm{C}} \text { PROBABILITY }\end{array}$} \\
\hline & & $\mathrm{O}^{\mathrm{b}}$ & & & $\mathrm{O}$ & & & $\mathrm{O}$ & & \\
\hline DEGREE OF INVOLVEMENT & A & & $\%$ & A & & $\%$ & A & & $\%$ & \\
\hline Proximal fibula & & 3 & & & 3 & & & 6 & & $p=1.0000$ \\
\hline None & 3 & 3 & 100.0 & 2 & 2 & 66.7 & 5 & & 83.3 & \\
\hline Slight & 0 & ) & 0.0 & 1 & 1 & 33.3 & 1 & & 16.7 & \\
\hline Total knee & & 25 & & & 26 & & & 51 & & $p=0.4986$ \\
\hline Absent & 19 & & 76.0 & 22 & & 84.6 & 41 & & 80.4 & \\
\hline Present & 6 & 5 & 24.0 & 4 & 4 & 15.4 & 10 & & 19.6 & \\
\hline Ankle & & & & & & & & & & \\
\hline Distal tibia & & 8 & & & 7 & & & 15 & & $p=0.0769^{\star}$ \\
\hline None & 4 & $t$ & 50.0 & 7 & & 100.0 & 11 & & 73.3 & \\
\hline Slight & 4 & $t$ & 50.0 & 0 & ) & 0.0 & 4 & & 26.7 & \\
\hline Distal fibula & & 8 & & & 5 & & & 13 & & $p=0.4872$ \\
\hline None & 6 & 5 & 75.0 & 5 & & 100.0 & 11 & & 84.6 & \\
\hline Slight & 2 & 2 & 25.0 & 0 & & 0.0 & 2 & & 15.4 & \\
\hline Total ankle & & 16 & & & 12 & & & 28 & & $p=0.0237^{\star}$ \\
\hline Absent & 10 & & 62.5 & 12 & & 100.0 & 22 & & 78.6 & \\
\hline Present & 6 & 5 & 37.5 & 0 & & 0.0 & 6 & & 21.4 & \\
\hline Foot & & & & & & & & & & \\
\hline Talus & & 11 & & & 7 & & & 18 & & $p=0.6305$ \\
\hline None & 4 & t & 36.4 & 4 & & 57.1 & 8 & & 44.4 & \\
\hline Slight & 6 & 5 & 54.5 & 3 & & 42.9 & 9 & & 50.0 & \\
\hline Moderate & 1 & & 9.1 & 0 & b & 0.0 & 1 & & 5.6 & \\
\hline Calcaneus & & 7 & & & 6 & & & 13 & & $p=0.1923$ \\
\hline None & 4 & t & 57.1 & 6 & & 100.0 & 10 & & 76.9 & \\
\hline Slight & 3 & 3 & 42.9 & 0 & & 0.0 & 3 & & 23.1 & \\
\hline Other tarsals & & 10 & & & 7 & & & 17 & & $p=0.5368$ \\
\hline None & 9 & ) & 90.0 & 5 & & 71.4 & 14 & & 82.4 & \\
\hline Slight & 1 & & 10.0 & 2 & 2 & 28.6 & 3 & & 17.6 & \\
\hline Metatarsals & & 18 & & & 11 & & & 29 & & $p=0.2685$ \\
\hline None & 15 & & 83.3 & 11 & & 100.0 & 26 & & 89.7 & \\
\hline Slight & 2 & 2 & 11.1 & 0 & 0 & 0.0 & 2 & & 6.9 & \\
\hline marked & 1 & & 5.6 & 0 & ) & 0.0 & 1 & & 3.4 & \\
\hline Foot phalanges & & 14 & & & 9 & & & 23 & & $p=0.2530$ \\
\hline None & 11 & & 78.6 & 9 & 9 & 100.0 & 20 & & 87.0 & \\
\hline Slight & 2 & 2 & 14.3 & 0 & ) & 0.0 & 2 & & 8.7 & \\
\hline Marked & 1 & & 7.1 & 0 & ) & 0.0 & 1 & & 4.3 & \\
\hline Total foot & & 60 & & & 40 & & & 100 & & $p=0.0845^{\star}$ \\
\hline Absent & 43 & & 71.7 & 35 & & 87.5 & 78 & & 78.0 & \\
\hline Present & 17 & & 28.3 & 5 & 5 & 12.5 & 22 & & 22.0 & \\
\hline Total appendicular & & 302 & & & 215 & & & 517 & & $p=0.0100^{\star}$ \\
\hline Absent & 230 & & 76.2 & 184 & & 85.6 & 414 & & 80.1 & \\
\hline Present & 72 & & 23.8 & 31 & & 14.4 & 103 & & 19.9 & \\
\hline
\end{tabular}

${ }^{\text {a }}$ Functional units following Douglas (1996:91) where applicable.

${ }^{\mathrm{b}} \mathrm{O}$, observed; A, affected; frequencies per bone.

${ }^{c}$ FET, Fisher's Exact Test, two-tailed probabilities reported.

* Distribution is statistically significant at 10 percent level. 
the shoulder and knee regions (Francken et al. 2010:20). At Ban Chiang, northeast Thailand, a Neolithic to early Iron Age site (Pietrusewsky and Douglas 2002), analysis of DJD patterns in the appendicular skeleton suggests males experienced more mechanical or repetitive stress throughout their body and at an earlier age than females (Douglas 1996:244). At the early Neolithic to late Iron Age site of Ban Non Wat in northeast Thailand, Domett and colleagues (2014) reported osteoarthritis occurred most often in the shoulders, elbows, knees, and feet, with consistent patterns through time, although published data are not available.

\section{Cultural Modification of Teeth}

Cultural alterations of dentition are often dichotomized as incidental (e.g., wear from using teeth as tools, betel staining from chewing Areca catechu nut) or intentional (e.g., purposeful filing or incising of the enamel, deliberate extraction of teeth, decorating or blackening teeth). Four types of cultural dental modifications that occur in Protohistoric/ Iron Age skeletons from Cambodia and Vietnam are assessed for their impact on oraldental health: enamel staining, intentional filing of the teeth, the use of teeth as tools, and the deliberate extraction of teeth (tooth ablation). At Vat Komnou, enamel staining was systematically recorded in each permanent tooth as absent or present, and the crown surface location of the staining (i.e., lingual, buccal, or circumferential) and color were described. Each case of suspected intentional tooth filing was described in detail. To assess the use of teeth as tools and differences in dental wear patterns, the degree of dental attrition was scored as none, enamel, dentin, pulp, or root. Although tooth ablation is difficult to demonstrate conclusively in archaeological remains, it may be detected in a sample by the patterning and frequency of antemortem tooth loss despite good oraldental health in the affected individuals (Milner and Larsen 1991:363; Pietrusewsky and Douglas 1993:261). At Vat Komnou, deliberate tooth removal was systematically recorded as absent or present for each permanent tooth, and only included adults (at least 15 years of age) with at least one incisor or canine scored. Although tooth ablation is absent in the Vat Komnou sample, it warrants discussion in this article as it is the most common type of purposeful dental modification in the region and occurs in all of the other comparative samples from Cambodia.

Cultural practices such as dental filing, using teeth as tools, or betel chewing, which promote advanced enamel wear and exposure of the pulp cavity, leave the teeth and surrounding bone vulnerable to infection and carious destruction. Dental modifications which expose the pulp cavity can potentially negatively affect oral-dental health and are assessed for association with dental pathologies (e.g., caries, periapical cavities, dental calculus, and alveolar resorption). Dental caries are defined as "progressive demineralization of the enamel, cementum, and dentine of the tooth by organic acids, which are produced through the fermentation of dietary carbohydrates by some plaque bacteria," with sugar the main cause of caries (Hillson 2008:313). Dietary habits such as the consumption of soft, sticky, and sweet foods and poor oral hygiene are associated with carious lesion formation (Lieverse et al. 2007:329). In the Vat Komnou dental sample, carious lesions were systematically scored per tooth as none, occlusal surface, interproximal surface including cervical region, smooth surface, cervical caries excluding interproximal region, root caries, and huge caries (following Buikstra and Ubelaker 1994:55). A periapical cavity, bone loss usually found at the apex of the tooth root, is the result of periapical inflammation due to infection of the pulp chamber (Hillson 2008). 
Periapical lesions were described in detail and systematically recorded as none, less than $3 \mathrm{~mm}$, greater than $3 \mathrm{~mm}$, and greater than $15 \mathrm{~mm}$ (following Clarke and Hirsch 1991a; Dias and Tayles 1997; Hillson 2008). While its etiology is multifactorial, the primary pathological agent of periodontal disease is large colonies of nonmineralized bacterial plaque, which adhere to mineralized plaque (calculus) and promote the bony response of alveolar resorption (Lieverse et al. 2007:330-331). Calculus was systematically recorded on all permanent teeth as none, slight, moderate, and marked (following Brothwell 1981). Alveolar resorption, bone loss of the alveolar process due to inflammation, was systematically scored as the degree of porosity of the cortical bone surrounding the alveolar socket, using a scale of none, slight (evidence of porosity), moderate (more advanced porosity), and marked (macroporosity) (following Douglas 1996:32).

Tooth Staining - Staining of the dental enamel surface may be the incidental result of habitual betel chewing or the deliberate attempt to attain a particular appearance. Betel chewing is a widespread practice in the Pacific-Asia region, with an estimated 400 million habitual chewers (Office of Planning and Statistics 1995:2). Preparing the betel quid (often referred to as "betel nut") for chewing typically involves "wrapping slivers of the seed ('areca nut') of the areca palm (Areca catechu L., Arecaceae) with slaked lime (calcium hydroxide) in a betel leaf (Piper betle L., Piperaceae)" (Zumbroich and Salvador-Amores 2009:126). The earliest archaeological evidence of $A$. catechu palm is found at Spirit Cave in Thailand over 10,000 years ago and eastern Timor 13,000-4000 years ago, although betel-stained teeth are not documented in the bioarchaeological record until 5000 B.P. in the Philippines (Fitzpatrick et al. 2003). While it may be difficult to distinguish intentional staining (i.e., dyeing or blackening teeth) from incidental betel staining in archaeological samples, as the two may occur simultaneously, purposeful staining is expected to be more intense and evenly distributed on the labial and lingual surfaces of the anterior tooth crowns but barely discernible in the posterior teeth, while incidental staining may be less distinct and found differentially throughout the dentition. However, not all purposeful staining is necessarily dark. Light intentional staining could be attributed to a dye that fades over time. While various "tooth blackening" concoctions have been documented elsewhere (Dark 1987:37; Krämer 1926; Lévesque 1996:75), the ability to distinguish incidental from intentional staining in bioarchaeological samples may be complicated by the simultaneous use of areca nut for both tooth dyeing and chewing, as documented in the Philippines (Zumbroich 2007:103).

Extensive betel chewing is associated with a lower prevalence of dental caries in some groups, including reduced food consumption, heavier saliva flow, an increased alkaline environment, and accelerated wear (dental attrition) which removes potential caries loci (Powell 1985:315). An increased alkaline environment and diets high in protein promote dental calculus formation (Lieverse 1999:219).

Incidental light brown to dark red-brown staining of the permanent dental enamel, presumed to be the result of betel chewing, is observed in 90.9 percent $(30 / 33)$ of the Vat Komnou adults, occurring nearly equally in 90.0 percent $(18 / 20)$ of the males and 92.3 percent $(12 / 13)$ of the females. The per tooth rate of betel staining is 76.0 percent $(218 / 287)$ in males and 65.9 percent $(139 / 211)$ in females. More male molars $(65 / 120$ or 54.2 percent) are affected than female molars (30/88 or 34.1 percent), a distribution that is statistically significant (FET, $p=0.0049)$. Betel chewing may have contributed to the higher (per tooth) rates of advanced calculus (26.2 percent) and advanced wear 


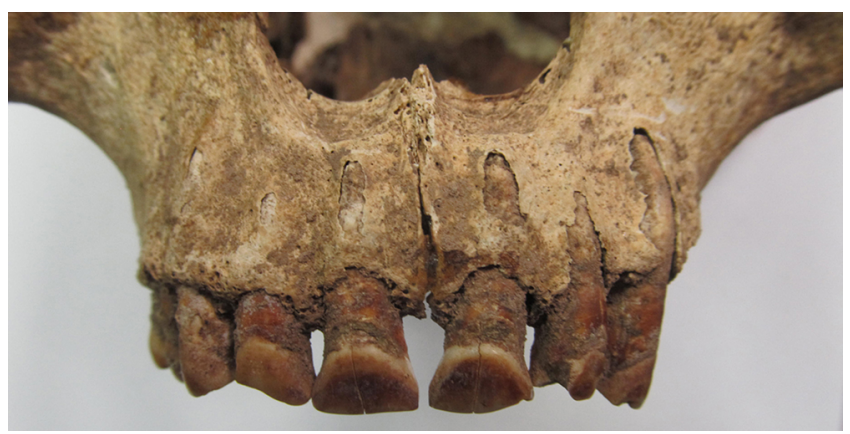

Fig. 9. Probable intentionally stained teeth of Vat Komnou Burial 43B, a 45-55+ year-old male. Photo by Rona Ikehara-Quebral.

(11.6 percent) in Vat Komnou males compared to females (13.1 percent and 8.9 percent, respectively), although neither of these distributions is statistically significant. Dental staining in one adult male appears to be intentional, as a dark reddish-brown stain is visible on the labial/buccal surfaces of the anterior maxillary teeth and first molars, but absent on the lingual surfaces (Fig. 9).

Since betel chewing is cariostatic and associated with increased periodontal disease (Douglas et al. 1997; Pietrusewsky, Douglas, et al. 2011, 2014), the prevalence of individuals with betel-stained teeth at Vat Komnou suggests this practice contributed to a low caries rate (5.0 percent) while detrimentally promoting advanced calculus accumulation (20.8 percent). Betel-stained teeth were reported 3000-1670 B.P. in 74.2 percent (23/31) of the Bronze/Iron Age individuals from Nui Nap in northern Vietnam near Man Bac, occurring in more female individuals (9/11 or 81.8 percent) than male individuals $(9 / 13$ or 69.2 percent) and in 50.4 percent $(281 / 558)$ of the teeth, but the pattern of concentrated staining on the labial surfaces of the anterior teeth suggests the staining may have been purposeful (Oxenham et al. 2002:911). Although seven out of the eight individuals with caries also had betel-stained teeth (possibly due to the topical application of betel quid juice rather than from prophylactic betel chewing), and only 15 out of 23 individuals with no caries had betel-stained teeth, there is no statistical correlation between caries and betel staining at this site (FET, $p=0.3791$ ) (Oxenham et al. 2002:911). At the Iron Age site Prohear in southeast Cambodia, dark reddish-brown staining concentrated on the anterior enamel surface of the front teeth, but was not found in the posterior teeth, suggests intentional staining occurred in at least one individual (Krais et al. 2012). Tooth staining was not reported for any of the sites in northwest Cambodia, suggesting that during the Protohistoric/Iron Age Period, both incidental and deliberate staining may have been geographically restricted to southern Cambodia and northern Vietnam, although its occurrence may have extended further south to Giong Co Vo, Vietnam, by the end of the Bronze Age (c. 2500 B.P.) (Oxenham et al. 2002:914).

Dental Filing - Intentional tooth filing is documented in ethnographic studies of Island Southeast Asia, including Indonesia, Borneo, and the Philippines (Domett et al. 2013:284). While tooth filing is found in several bioarchaeological samples from Cambodia, this practice is not reported in samples from Vietnam or Thailand. At Vat Komnou, the upper and lower anterior teeth (permanent incisors and canines) of two 


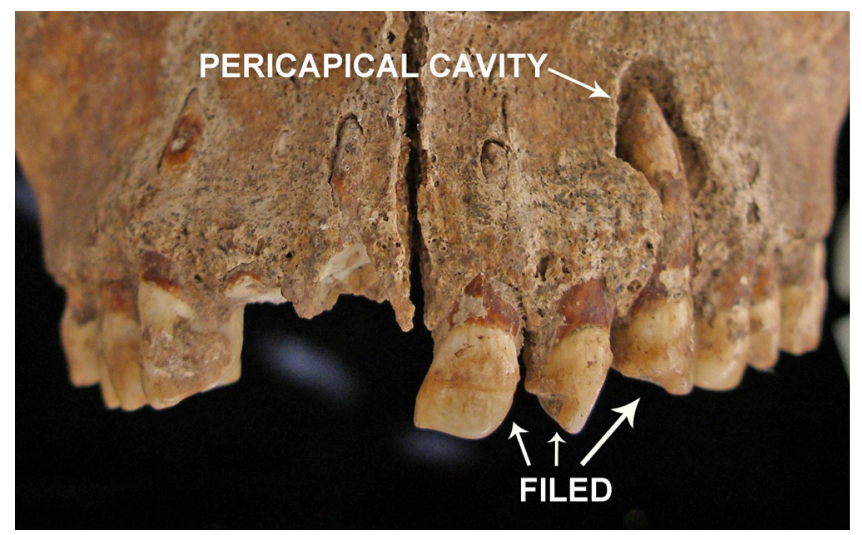

Fig. 10. Filed maxillary permanent left incisors and canine of Vat Komnou Burial 36, a 35-45-year-old male. A periapical cavity surrounds the canine root. Photo by Rona Ikehara-Quebral.

males and two females appear to be deliberately filed with a rounded tool to create interproximal grooves or notches extending to the crown edges, in adjacent teeth, and usually occurring in the antimeres (Fig. 10). In the maxilla, the mesial and distal enamel surfaces of the lateral incisors and canines are filed, creating a blunt point, while the only preserved maxillary central incisor in affected individuals is filed on the mesial edge only. In the mandible, the central incisor is either filed to a point or is extremely worn, the lateral incisor is always filed to a point, and the canine may be filed to a point or only affected on the mesial edge. In one individual all mandibular incisors and canines are filed to a point. Interproximal filing of at least one anterior permanent tooth occurs in 16.0 percent (4/25) of the Vat Komnou individuals over 15 years of age, affecting 16.7 percent $(2 / 12)$ of the females and 15.4 percent $(2 / 13)$ of the males, with no significant sex distribution. Carious destruction of the filed tooth surfaces is absent in all four individuals with tooth filing, but calculus formation appears to be greater in filed teeth relative to unfiled teeth in two of the individuals.

The two Vat Komnou males with deliberate tooth filing, Burials 32 and 36, each have a single periapical cavity in the alveolar region associated with filed teeth (mandibular right central incisor and maxillary left canine). While sample size is too small to determine a correlation between tooth filing (with pulp exposure) and infection of the surrounding bone, in both individuals filing exposed the dental pulp. Pulp exposure inevitably results in infection of the tooth and eventually the surrounding bone (Clarke and Hirsch 1991b:297). When the pulp is invaded by pathogenic microorganisms and their toxins, it can become inflamed, and ifleft untreated, this will progress to pulp necrosis and infection (Yu and Abbott 2007:S4), and subsequently spread to the surrounding alveolar bone (i.e., periapical cavity formation). The overall periapical cavity rate at Vat Komnou is 1.9 percent (10/523 alveoli), affecting eight individuals (four of the 17 males and four of the 13 females). Eight affected tooth sockets in the six individuals with no dental filing include the maxillary canine, third premolar (three cases), and second and third molars, and the mandibular third and fourth premolars. At least five of the eight (62.5 percent) individuals with periapical cavities have dental pulp exposure in the affected or adjacent teeth.

Intentional dental filing is reported in only four of the seven samples from Cambodia, and is restricted to the Protohistoric/Iron Age Period (Table 9). Purposeful 
Table 9. Intentional Tooth Filing in Cambodia (Recorded in permanent teeth in INDIVIDUALS $>15$ YEARS)

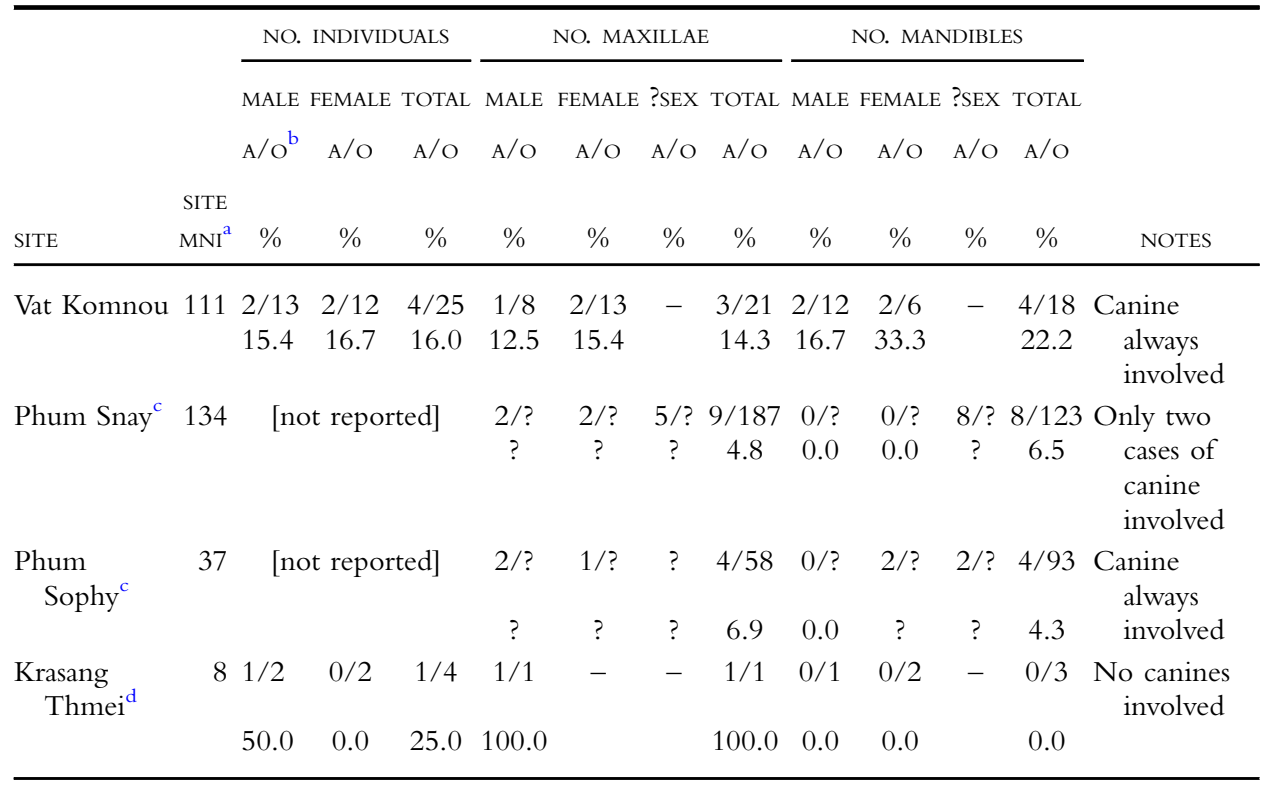

${ }^{a}$ MNI, minimum number of individuals. Ossuary collections at Phum Snay and Phum Sophy augment the MNI for each jaw.

${ }^{\mathrm{b}} \mathrm{A} / \mathrm{O}$, affected/observed. Only individuals/jaws with at least one observed incisor or canine are included for Vat Komnou and Krasang Thmei.

${ }^{\mathrm{c}}$ Four maxillae at Phum Sophy are reported as affected (Domett et al. 2013:279), although only three are listed by sex in Table 3 in Domett et al. (2013:281).

${ }^{\mathrm{d}}$ Domett (2005).

dental filing occurred bilaterally in the maxilla and mandible, with anterior teeth filed either to a point or with just one (mesial or distal) tooth crown edge affected. At Phum Snay and Phum Sophy, 4.3-6.9 percent of the upper or lower jaws were affected and several patterns (four in the maxilla and six in the mandible) of dental filing involved the anterior teeth in either jaw (Domett et al. 2013:279). Only maxillae and mandibles with a complete set of anterior teeth (canines, lateral, and central incisors) were included in the analysis, although the actual rate of affected jaws might be higher if only jaws with at least one observed incisor or canine were included. The Phum Sophy sample always involved canines, while this is true for only two cases at Phum Snay. At Vat Komnou, at least one canine is always involved in each affected individual with no clear pattern. At Krasang Thmei, one individual (1/4 or 25.0 percent), a possible male, had intentional filing of his upper left central incisor (Domett 2005:7). Analyzed per jaw, both Vat Komnou (maxillae and mandibles) and Krasang Thmei (maxillae) have higher frequencies of filing than Phum Snay and Phum Sophy, although sample sizes are too small to test for significance. In summary, filing at Phum Sophy and Vat Komnou involved at least one canine in the upper or lower jaw, with a variety of patterns represented in these samples from Cambodia.

The correlation between two oral-dental health indicators (caries and periapical cavities) and dental filing in the Phum Snay and Phum Sophy samples cannot be determined because individual data were not reported, although these two samples had 
much higher group frequencies of these two indicators than the Vat Komnou sample. At Krasang Thmei, dental caries were absent in the filed tooth and periapical cavities could not be recorded, likely due to poor preservation of the surrounding alveolar bone (Domett 2005). A larger sample is needed to test for a correlation between oraldental health and filing at Vat Komnou.

Teeth as Tools - Teeth can record the pathological effects of non-masticatory activities that result in distinctive patterns of abrasion, crown fractures, or traumatic tooth loss (Larsen 2015:288). Here, we briefly discuss wear patterns that could indicate the use of teeth as tools. Dental wear patterns in the Vat Komnou adult sample were analyzed for age and sex differences (Ikehara-Quebral 2010). Overall, dental attrition (slight, moderate, or marked degrees) is nearly equal in male (97.5 percent) and female (98.5 percent) teeth, and is most commonly dentin exposure. In the mandible, advanced attrition (wear to the pulp or root) occurs in significantly more male teeth $\left(22 / 154\right.$ or 14.3 percent) than female teeth ( $3 / 83$ or 3.6 percent) (Yates $\chi^{2}=5.427$, $d f=1, p=0.0198)$, which suggests males had a more fibrous diet than females, although the use of teeth as tools cannot be ruled out. The use of teeth as tools could also have contributed to the unusual wear patterns and interproximal notches observed in the filed teeth of Vat Komnou males and females, and should be investigated further, including the analysis of enamel chipping and fracture patterns.

Tooth Ablation - Tooth ablation, the deliberate removal of anterior teeth in the living, has been recorded in archaeological samples as far-flung as Japan, Taiwan, Southeast Asia, Africa, Europe, Siberia, the New World, and Australia (Kusaka et al. 2009; Pietrusewsky and Douglas 1993; Pietrusewsky, Lauer, et al. 2014; Tayles 1996) (Fig. 11). Ablation of the anterior teeth may mark a rite of passage such as the onset of puberty, marriage, a mourning ritual, or indicate group membership (Pietrusewsky and Douglas 1993:255). The purposeful removal of anterior teeth in an archaeological sample is presumed by a repeated symmetrical pattern of antemortem tooth loss in multiple individuals despite the appearance of otherwise good oral-dental health, and is even more compelling when this practice is documented in early historic records. Congenital absence of anterior teeth, rather than their intentional removal or pathological loss, can be ruled out if there are interproximal wear facets on the adjacent teeth and adequate residual space for the missing teeth (Nelsen et al. 2001:964), but in practice this may be difficult to discern due to postmortem loss of adjacent teeth and damage to the alveolar bone.

While deliberate tooth removal is absent $(0 / 17$ males, $0 / 13$ females) in the Vat Komnou, southern Cambodia dental sample, it was documented at seven Iron Age sites in northwest Cambodia, suggesting cultural affinities or migration between these neighboring sites (Chhem et al. 2004; Domett 2005; Domett et al. 2013; Frelat and Souday 2015; Frelat et al. 2016) (Table 10). Ablation was also found at Iron Age site Gò Ô Chùa in southern Vietnam (Francken et al. 2010:19-20). At the Iron Age site Noen U-Loke, Thailand (Nelsen 1999:95; Nelsen et al. 2001; Tayles et al. 2007:281-284), where 120 individuals were recovered, at least one lateral incisor is missing in 30/38 individuals (78.9 percent). Since congenital absence cannot be ruled out for 42 percent of the Noen U-Loke lateral incisors (due to inadequate alveolar space between the central incisor and canine, which suggests the teeth were never present), this site is excluded from further discussion. Ablation was also recorded at three Neolithic sites in Vietnam and Thailand (Domett et al. 2013; Oxenham and Domett 2011:82; Sangvichien et al. 1969; Tayles 1996:336-337). 


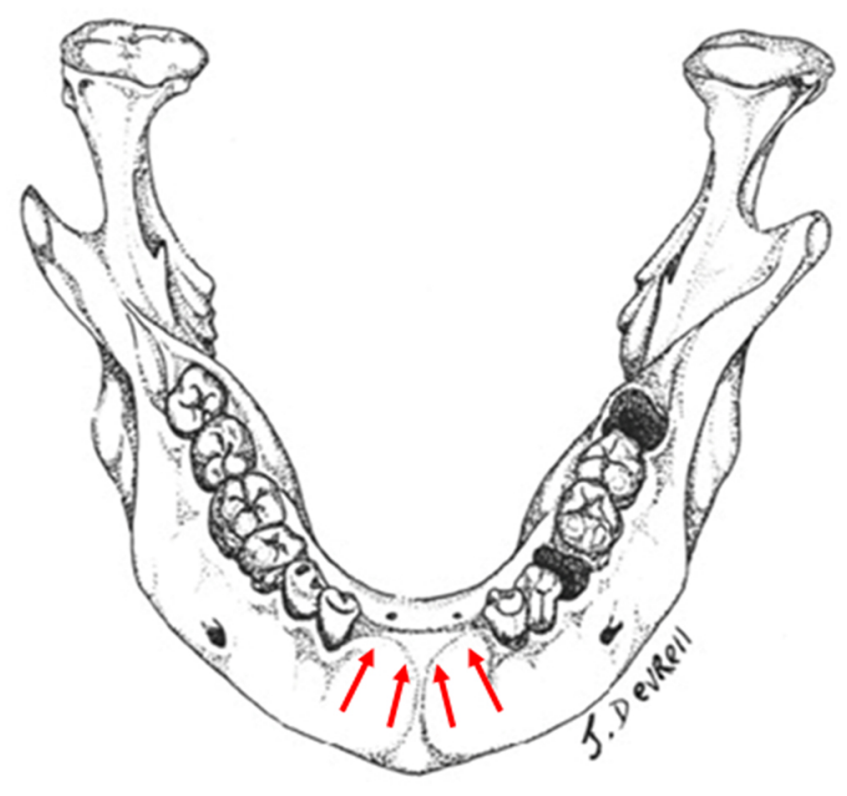

Fig. 11. Example of a mandible with tooth ablation of all four incisors (arrows showing where teeth were removed), occurring well before death with subsequent alveolar bone resorption. Drawn by Julia Devrell, PHRI. (From Pietrusewsky and Douglas [1993:264], used with permission from The Journal of the Polynesian Society.)

The range of variation in Iron Age samples includes most commonly a bilateral removal of maxillary lateral incisors at Phum Snay and Phum Sophy (Domett et al. 2013), probable ablation of all mandibular incisors in two cases at Krasang Thmei (Domett 2005), and a bilateral removal of maxillary lateral incisors and canines in two individuals at Koh Ta Méas (Frelat and Souday 2015). In Early Neolithic samples, a bilateral removal of one to two mandibular incisors occurred at Con Co Ngua, Vietnam (Oxenham 2000:197), and the ablation of maxillary lateral incisors, usually bilaterally, occurred at Khok Phanom Di, Thailand (Domett et al. 2013; Tayles 1996:336-337). Both maxillary central incisors were always ablated during the Late Neolithic period at Khok Phanom Di, occurring in 100 percent of the 22 individuals with teeth.

To examine temporal changes in the tooth ablation rates in the Southeast Asia samples reported in Table 10, we substituted the number of affected/observed maxillae reported by Domett and colleagues (2013) for the number of affected individuals at Phum Snay and Phum Sophy, and samples of similar temporality were combined into a single sample (excluding Prei Khmeng, Koh Krabas, and Man Bac due to incomplete data). The Protohistoric/Iron Age tooth ablation rate (91/234 individuals or 38.9 percent) is very similar to the overall Neolithic rate $(61 / 159$ individuals or 38.4 percent) and the Early Neolithic rate (39/123 individuals or 31.7 percent). However, a statistically significant (FET, $p=0.0019)$ difference in tooth ablation rates is found in the Early Neolithic sample (31.7 percent) compared to the Late Neolithic sample (22/36 individuals or 61.1 percent), and a significant difference exists between the Late Neolithic (61.1 percent) and the Protohistoric/Iron Age (38.9 percent) samples (FET, $p=0.0174)$. Although some of the reported data 
Table io. Tooth Ablation in Southeast Asia (recorded in permanent teeth of INDIVIDUALS $>15$ YEARS)

\begin{tabular}{|c|c|c|c|c|c|}
\hline & & NO. INDIVIDUALS & NO. MAXILLAE NO. & MANDIBLES & \\
\hline & & TOTAL & TOTAL & TOTAL & \\
\hline & & $\mathrm{A} / \mathrm{O}^{\mathrm{a}}$ & $\mathrm{A} / \mathrm{O}$ & $\mathrm{A} / \mathrm{O}$ & \\
\hline SITE & SITE MNI ${ }^{\mathrm{a}}$ & $\%$ & $\%$ & $\%$ & NOTES \\
\hline
\end{tabular}

\section{Protohistoric/Iron Age}

\section{Southern Cambodia}

Vat Komnou $^{\text {b }} \quad 111$

Northwest Cambodia

$\begin{array}{lccll}\text { Phum Snay }^{c} & 134 & \text { [not reported] } & 74 / 123 & 15 / 70 \\ & & & 60.2 & 21.4 \\ \text { Phum Sophy }^{c} & 37 & \text { [not reported] } & 11 / 23 & 3 / 39 \\ & & & 47.8 & 7.7\end{array}$

\begin{tabular}{|c|c|c|c|c|}
\hline $\begin{array}{l}\text { Phum Krasang } \\
\text { Thmei }^{\mathrm{d}}\end{array}$ & 8 & $\begin{array}{l}3 / 5 \\
60.0\end{array}$ & $\begin{array}{l}1 / 1 \\
100.0\end{array}$ & $\begin{array}{l}2 / 5 \\
40.0\end{array}$ \\
\hline Koh Ta Mèas ${ }^{\mathrm{e}}$ & 24 & $\begin{array}{l}3 / 8 \\
37.5\end{array}$ & $\begin{array}{l}3 / 8 \\
37.5\end{array}$ & [not reported] \\
\hline
\end{tabular}

Prei Khmeng $^{\mathrm{f}} \quad 7 \quad 1 / 1$ ?

Koh Krabas ${ }^{\mathrm{g}}$

Gò Ô Chùa $^{\mathrm{h}} \quad 52 \quad \begin{aligned} & 1 / 32 \\ & 3.1\end{aligned}$

\section{Thailand}

Ban $\mathrm{Kao}^{\mathrm{i}}$

\section{Neolithic ${ }^{j}$}

\section{Vietnam}

\begin{tabular}{lccc} 
Man Bac $^{\mathrm{k}}$ & $\sim 47$ & \multicolumn{2}{c}{ [not reported] } \\
Con Co Ngua & 94 & $9 / 74$ & [not reported] \\
(Da but & & 12.2 & \\
Period/Early & & & \\
Neolithic) & & &
\end{tabular}

$\begin{array}{lll}0 / 27 & 0 / 19 & \text { No ablation observed. } \\ 0.0 & 0.0 & \end{array}$

Usually symmetrical ablation. Combining Phum Snay with Phum Sophy, max. lateral incisors most commonly removed.

Probable ablation of all mand. incisors in two cases.

Bilateral ablation of max. lateral incisors and canines in two females; max. of third female incomplete.

Only one adult observed? No details provided. [not reported]

No details provided.

$$
\text { [not reported] }
$$

Two incisors missing in one male individual. No other details provided.

No Iron Age individuals were affected at Ban Kao, only Early Neolithic individuals (below).

Ablation suspected but no details provided.

Ablation suspected; all nine cases over 40 years of age: eight individuals display symmetrical removal of two or four mand. incisors while 9th case mand. left incisors ablated; at least four of these cases involved other teeth removed antemortem. 
TABLE 10. (Continued)

\begin{tabular}{|c|c|c|c|c|c|}
\hline SITE & SITE MNI ${ }^{a}$ & $\begin{array}{l}\text { NO. INDIVIDU } \\
\text { TOTAL } \\
\mathrm{A} / \mathrm{O}^{\mathrm{a}} \\
\%\end{array}$ & $\begin{array}{c}\text { NO. MAXILI } \\
\text { TOTAL } \\
\text { A/O } \\
\%\end{array}$ & $\begin{array}{c}\text { NO. MANDIBLES } \\
\text { TOTAL } \\
\text { A/O } \\
\%\end{array}$ & NOTES \\
\hline \multirow{2}{*}{\multicolumn{6}{|c|}{ Thailand }} \\
\hline & & & & & \\
\hline $\begin{array}{l}\text { Khok Phanom } \\
\text { Di }(E N)^{\mathrm{m}}\end{array}$ & $39+$ & $\begin{array}{l}25 / 38 \\
65.8\end{array}$ & $\begin{array}{l}\text { 23/? } \\
?\end{array}$ & $\begin{array}{l}6 / ? \\
?\end{array}$ & $\begin{array}{l}\text { At least one max. lateral } \\
\text { incisor always removed } \\
\text { but usually bilateral. } \\
\text { Excludes one unaffected } \\
\text { child. }\end{array}$ \\
\hline $\begin{array}{l}\text { Khok Phanom } \\
\text { Di }(\mathrm{LN})^{\mathrm{m}}\end{array}$ & $30+$ & $\begin{array}{l}22 / 22 \\
100.0\end{array}$ & $\begin{array}{l}22 / 22 \\
100.0\end{array}$ & $\begin{array}{l}12 / ? \\
?\end{array}$ & $\begin{array}{l}\text { Of individuals with teeth, } \\
100 \% \text { affected. Both max. } \\
\text { central incisors always } \\
\text { ablated. Females more } \\
\text { teeth removed than males, } \\
\text { most often in mand. }\end{array}$ \\
\hline $\begin{array}{l}\text { Khok Phanom } \\
\text { Di (total } \\
\text { Neolithic) }^{\mathrm{m}}\end{array}$ & 80 & $47 / 60$ & $45 / ?$ & $18 / ?$ & $\begin{array}{l}\text { Excludes three out of eight } \\
(37.5 \%) \text { children affected } \\
\text { in Late Neolithic. }\end{array}$ \\
\hline Ban Kao $(E N)^{i}$ & 16 & $\begin{array}{l}5 / 11 \\
45.5\end{array}$ & $\begin{array}{l}5 / 11 \\
50.0\end{array}$ & $\begin{array}{l}5 / 13 \\
38.5\end{array}$ & $\begin{array}{l}\text { All with bilateral removal of } \\
\text { max. lateral incisors and } \\
\text { canines; youngest 17-18 } \\
\text { years. }\end{array}$ \\
\hline $\operatorname{Ban} \mathrm{Kao}(\mathrm{LN})^{\mathrm{i}}$ & 17 & $\begin{array}{l}0 / 14 \\
0.0\end{array}$ & $\begin{array}{l}0 / 11 \\
0.0\end{array}$ & $\begin{array}{l}0 / 10 \\
0.0\end{array}$ & $\begin{array}{l}\text { No Late Neolithic } \\
\text { individuals were affected. }\end{array}$ \\
\hline $\begin{array}{l}\text { Ban Kao (total } \\
\text { Neolithic) }^{\mathrm{i}}\end{array}$ & 33 & $5 / 25$ & $5 / 22$ & $5 / 23$ & $\begin{array}{l}\text { Only Early Neolithic } \\
\text { individuals were affected; } \\
\text { two Iron Age individuals } \\
\text { are excluded here. }\end{array}$ \\
\hline
\end{tabular}

${ }^{a}$ MNI, minimum number of individuals, including subadults. Ossuary collections at Phum Snay and Phum Sophy augment the MNI for each jaw; A/O, affected/observed.

${ }^{\mathrm{b}}$ This study. Includes only individuals with at least one incisor or canine available for observation.

${ }^{\mathrm{c}}$ Domett et al. (2013).

${ }^{\mathrm{d}}$ Domett (2005).

${ }^{\mathrm{e}}$ Frelat and Souday (2015). Includes only individuals with anterior maxilla preserved.

${ }^{\mathrm{f}}$ Chhem et al. (2004); Domett et al. (2013:280).

${ }^{\mathrm{g}}$ Domett et al. (2013:280).

${ }^{\text {h }}$ Francken et al. (2010:19-20); Reinecke et al. (2009:109).

${ }^{\mathrm{i}}$ Sangvichien et al. (1969). Frequencies in individuals $>15$ years compiled (this study) from burial descriptions and photographs.

${ }^{\mathrm{j}}$ EN, Early Neolithic; LN, Late Neolithic.

${ }^{\mathrm{k}}$ Oxenham and Domett (2011:82).

${ }^{1}$ Oxenham (2000:197).

${ }^{\mathrm{m}}$ Domett et al. (2013); Tayles (1996:336-337).

Note: At least one lateral incisor is missing in 30/38 individuals (78.9 percent) at Iron Age site Noen ULoke, Thailand (Nelsen 1999; Nelsen et al. 2001; Tayles et al. 2007:281-284; $N=120$ individuals recovered), but congenital absence of lateral incisors cannot be ruled out in the most cases. 
had to be re-interpreted to enable these comparisons, there appears to be a highly significant increase in the practice of tooth ablation from early to late Neolithic times, and then a significant decrease from late Neolithic to the Protohistoric/Iron Age Period.

Root remnants in partially remodeled alveolar sockets suggest tooth extraction occurred by knocking out rather than pulling out teeth in seven cases at Phum Snay and Phum Sophy (Domett et al. 2013:278). The traumatic removal of teeth could cause soft tissue damage or fracturing of the surrounding alveolar bone, possibly leading to infection and necrosis of tooth remnants. In 13 Southeast Asia samples surveyed, the samples with the highest frequencies of periapical lesions (from Khok Phanom Di, Noen U-Loke, Phum Snay, and Phum Sophy) also had evidence of tooth ablation (Newton et al. 2013:7). However, in a more recent study, it appears that tooth ablation is not associated with poorer dental health in prehistoric Southeast Asia (Newton and Domett 2014:195).

\section{Oral-dental Health}

The study of Vat Komnou teeth and the surrounding alveolar bone allows us to make inferences about the health impact of dietary practices, including food preferences and their preparation. The oral-dental health of the Vat Komnou permanent tooth/ alveolus sample was assessed in individuals over 15 years of age (Table 11). An overall low rate of carious teeth (5.0 percent) and a moderate rate (10.4 percent) of advanced dental attrition suggest the consumption of fibrous, abrasive foods (including betel quid) that helped remove plaque bacteria from the teeth.

Vat Komnou males are more affected than females by advanced (moderate and marked) levels of calculus and alveolar resorption, two indicators of periodontal disease. Twice as many Vat Komnou male teeth (26.2 percent) as female teeth (13.1 percent) exhibit advanced levels of calculus, an extremely significant (FET, $p=0.0004)$ sex difference that is also found in young adults. Significantly (FET, $p=0.0116)$ more male sockets (21.2 percent) than female sockets (11.8 percent) are affected by advanced alveolar resorption. Sex differences in cultural practices that promote an alkaline oral environment, such as the consumption of a high protein diet or betel chewing, or poorer oral hygiene might account for more oral-dental disease in males.

Inter-site Comparisons - Per tooth caries rates were higher in females than males in 75.0 percent $(12 / 16)$ of the Southeast Asia dental samples surveyed by Newton and colleagues (2013:8-9) and at Gò Ô Chùa (males 18.8 percent, females 46.7 percent) (Francken et al. 2010:19). Newton and colleagues (2013:6-9) suggested that this trend, common in world-wide samples, may be the result of physiological factors differentially affecting males and females, including the rate of salivary consistency and flow, hormones, pregnancy, and high fertility. Despite the high fertility rate at Vat Komnou, male and female caries rates are not significantly different. In a previous study comparing dental data recorded in Vat Komnou and a number of Southeast Asia groups, there was no apparent temporal trend in rates of advanced attrition, carious lesions, and advanced periodontal disease (Ikehara-Quebral 2010:171-177). Differences in pathology rates in the Southeast Asia groups were attributed to local differences in diet and food preparation, physiological factors, use of teeth as tools, cultural dental modification, and oral hygiene. 
Table i i. Dental Pathology Profile of Permanent Dentitions (individuals $>15$ years) from Vat Komnou, Angkor Borei, Cambodia

\begin{tabular}{|c|c|c|c|c|c|c|c|c|c|c|c|c|}
\hline \multirow[b]{3}{*}{ DISEASE } & \multicolumn{6}{|c|}{ INDIVIDUALS } & \multicolumn{6}{|c|}{ TEETH/ALVEOLI } \\
\hline & \multicolumn{2}{|c|}{ MALES } & \multicolumn{2}{|c|}{ FEMALES } & \multicolumn{2}{|c|}{$\begin{array}{l}\text { TOTAL MALES } \\
\text { AND FEMALES }\end{array}$} & \multicolumn{2}{|c|}{ MALE } & \multicolumn{2}{|c|}{ FEMALE } & \multicolumn{2}{|c|}{$\begin{array}{l}\text { TOTAL TEETH/ } \\
\text { ALVEOLI }\end{array}$} \\
\hline & $\mathrm{A} / \mathrm{O}^{\mathrm{a}}$ & $\%$ & $\mathrm{~A} / \mathrm{O}$ & $\%$ & $\mathrm{~A} / \mathrm{O}$ & $\%$ & $\mathrm{~A} / \mathrm{O}$ & $\%$ & $\mathrm{~A} / \mathrm{O}$ & $\%$ & $\mathrm{~A} / \mathrm{O}$ & $\%$ \\
\hline $\begin{array}{l}\text { Antemortem tooth } \\
\text { loss }\end{array}$ & $4 / 21$ & 19.0 & $3 / 14$ & 21.4 & $7 / 35$ & 20.0 & $18 / 393$ & 4.6 & $5 / 254$ & 2.0 & $23 / 647$ & 3.6 \\
\hline Observed caries $^{\mathrm{b}}$ & $7 / 20$ & 35.0 & $5 / 14$ & 35.7 & $12 / 34$ & 35.3 & $16 / 283$ & 5.7 & $9 / 214$ & 4.2 & $25 / 497$ & 5.0 \\
\hline Periapical cavity & $4 / 17$ & 23.5 & $4 / 13$ & 30.8 & $8 / 30$ & 26.7 & $5 / 310$ & 1.6 & $5 / 213$ & 2.3 & $10 / 523$ & 1.9 \\
\hline Advanced calculus ${ }^{c}$ & $14 / 20$ & 70.0 & $5 / 13$ & 38.5 & $19 / 33$ & 57.6 & $74 / 282$ & $26.2^{\star}$ & $26 / 199$ & 13.1 & $100 / 481$ & 20.8 \\
\hline $\begin{array}{l}\text { Advanced alveolar } \\
\text { resorption }\end{array}$ & $11 / 17$ & 64.7 & $7 / 13$ & 53.8 & $18 / 30$ & 60.0 & $60 / 283$ & $21.2^{\star}$ & $21 / 178$ & 11.8 & $81 / 461$ & 17.6 \\
\hline Advanced attrition $^{\mathrm{d}}$ & $5 / 20$ & 25.0 & $4 / 14$ & 28.6 & $9 / 34$ & 26.5 & $33 / 285$ & 11.6 & $19 / 213$ & 8.9 & $52 / 498$ & 10.4 \\
\hline
\end{tabular}

${ }^{\mathrm{a}} \mathrm{A} / \mathrm{O}$, affected/observed; bold $=$ higher of male-female result.

${ }^{\mathrm{b}}$ A caries correction factor (Lukacs 1995:152) was not used here as there were no huge carious lesions (a proxy for pulp exposure due to caries) in this sample.

${ }^{c}$ Moderate or marked expressions; at least one tooth/alveolus affected in individuals.

${ }^{\mathrm{d}}$ Pulp exposure or wear to the roots; at least one tooth affected in individuals.

${ }^{\star}$ Significant sex distribution $(\alpha=0.10)$.

\section{SEXUAL DIVISION OF LABOR}

Several pathological changes of the skeleton discussed above support a distinct sexual division of labor at Vat Komnou, including differences in infection rates and the occurrence of DJD and trauma in specific areas of the skeleton. That only males are affected by chronic infection suggests males had a greater exposure to bacterial infection than females, and further suggests occupational differences such as more exposure to disease vectors when clearing land, tending animals, hunting, traveling to other regions, and perhaps more interaction with non-locals for trade, politics, and so on. Significant differences in the distribution of DJD throughout the appendicular and vertebral skeletons, reinforced by sex differences in trauma frequencies for the same anatomical regions (except no shoulder trauma), suggest a sexual division of labor that differentially affects the health of males and females beginning in early adulthood. Male activities such as plowing, net fishing, metal production, metalworking, carrying heavy loads, or hunting would stress the neck, shoulder, ankle, and foot regions, while female activities, such as bending forward to plant or harvest crops, childbearing, squatting to process or cook foods, and repetitive lifting of heavy objects would place more pressure on the middle and lower back and strain the sacroiliac joint (Ikehara-Quebral 2010).

\section{CULTURAL BUFFERS}

While this article focuses on cultural practices that could explain some of the skeletal and dental changes observed in the Vat Komnou cemetery sample, some of the cultural practices mentioned earlier would have buffered the Vat Komnou inhabitants from 
environmental instability, famine, and military threats, and helped to maintain good health. These practices include, but are not limited to, the construction of water features, walls and moats, a protein-rich diet, rice cultivation, and trade. Over 100 water features at Angkor Borei would have buffered the Vat Komnou inhabitants during the prolonged dry season caused by tropical monsoons, and could also provide a steady supply of fish. The brick walls and moats could have served a defensive purpose against human or flooding threats. Archaeological and isotopic evidence suggests there was abundant protein available and consumed at Angkor Borei and that the diet was rich in $\mathrm{C}_{3}$ foods (which includes rice). Archaeological evidence in Iron Age Southeast Asia shows a proliferation of village communities in major river valleys whose subsistence included rice cultivation. These settlements were on the margins of the floodplains which were suitable areas for wet-rice agriculture (Higham 2014). Presentday Angkor Borei is one of Cambodia's most productive rice farming regions and may have been an ideal location for rice farming in the past. Lastly, while a trade network with outsiders may have brought infectious disease, trade could have also provided a variety of foods, farming tools, livestock, medical supplies, new technologies and ideas, and other benefits which could have helped people maintain good health during a time of dramatic socio-cultural change.

\section{SUMMARY AND CONCLUSIONS}

During the Protohistoric Period, Mekong populations exploited a range of agricultural strategies, including the increasing reliance on rice that occurred throughout mainland Southeast Asia (Higham 2014; Weber et al. 2010). A broad-based hunting and gathering subsistence strategy is likely to have continued from prehistoric times, with new cultivars such as rice gradually added to the food spectrum and supplemented by a strong trade-based economy to increase dietary breadth and maintain good health. Until recently, there was no evidence of agricultural intensification (i.e., dependence on a few staple crops) and the associated cultural and environmental changes that were accompanied by dramatic declines in health in other parts of the world. In fact, most early Southeast Asia groups were relatively healthy (Domett and Tayles 2007; Douglas and Pietrusewsky 2007; Ikehara-Quebral 2010; Oxenham et al. 2006; Pietrusewsky and Douglas 2002) compared to groups that adopted intensive agricultural practices elsewhere (Cohen and Armelagos 1984; Cohen and Crane-Kramer 2007). Furthermore, there is no evidence in several Southeast Asia groups that an increased reliance on rice contributes to poorer health (Clark et al. 2014; Tayles et al. 2000) and no clear temporal trend of declining oral-dental health, which varies with the health indicator assessed (Ikehara-Quebral 2010; Newton and Domett 2014). However, Newton (2014) suggested that late Iron Age samples from Phum Snay and Phum Sophy show a high dependence on agricultural foods and she demonstrated a decline in health likely coinciding with an intensification of agriculture. Instead of a uniform regional trajectory, there appears to have been local variation in the timing and tempo of cultural and environmental changes that affected health.

Ancient human skeletal and dental remains recovered from a portion of the Vat Komnou cemetery mound, a protohistoric site in Angkor Borei, southern Cambodia, were examined for evidence of cultural practices that could affect health, including a sexual division of labor, dental modification, and diet. Skeletal changes suggest a distinct sexual division of labor, with male activities placing more stress on the neck, 
shoulder, ankle, and foot regions, and female activities affecting the middle to lower back and sacroiliac joint. The occurrence of chronic infectious disease in males (but not females) also suggests occupational differences that increased male exposure and limited female exposure to bacterial vectors. Intentional dental filing could have contributed to poorer oral-dental health in two individuals, although we could not test for a statistical significance due to insufficient data.

Angkor Borei's cultural importance as a regional center during the Funan period, its accessibility by waterways to other urban centers, and burial goods such as South Asia beads suggest Vat Komnou inhabitants participated in a maritime trade network, which would have promoted the easy transmittal of infectious disease and potentially introduced new diseases for which they had no natural immunity (Larsen and Milner 1994). Sudden death by acute illness would explain the low incidence of observed pathological changes in the Vat Komnou skeletons. During this period of intensified agriculture, there would also have been more exposure to zoonoses with the clearing of forests, bodies of standing water, the maintenance of farm animals, and higher population densities (Ikehara-Quebral 2010:191).

Stable isotope ratio analyses suggest that the Vat Komnou inhabitants had a relatively greater reliance on fish and estuarine/riverine dietary resources than on terrestrial protein compared to other bioarchaeological samples from Southeast and East Asia. Dental pathologies suggest that they consumed a mixed diet with a greater reliance on fibrous foods than soft, processed agricultural foods. Preliminary analysis of the nonhuman faunal remains recovered from Angkor Borei suggests a broad-spectrum diet and varied use of the local environment. Pottery and pig heads as mortuary offerings, intentional dental modifications, and immigrants buried at the Vat Komnou cemetery suggest cultural affinities and intermarriage with other groups in the region. Despite the increased exposure to disease vectors expected in an area easily accessible by waterways, and other social and environmental stressors that accompany increasing socio-complexity, the ancient inhabitants of Vat Komnou were a relatively tall, healthy group of people.

\section{FUTURE RESEARCH}

Although the bioarchaeological database of human skeletal remains from Cambodia is slowly growing, little is known about the health and cultural practices of its ancient inhabitants. Additional samples from Cambodia that span the late Bronze Age to late Iron Age, and which are large enough to test for differences between early and late phases in a single sample, would increase our understanding of local and regional health trends during the period of significant socio-cultural changes associated with early state formation.

A more detailed examination of trauma to the Vat Komnou teeth, including enamel chipping, fracture patterns, filing, and interproximal notches, would supplement the wear pattern data and increase our understanding of the cultural modification of teeth, including the use of teeth as tools, and its impact on oral-dental health.

Ongoing studies at Angkor Borei include faunal analysis to determine changes in the local environment over time and isotope studies of additional bone and tooth samples, including faunal remains, to further illuminate dietary and migratory practices. 


\section{ACKNOWLEDGMENTS}

The authors wish to thank the administration and staff of the Kingdom of Cambodia's Ministry of Culture and Fine Arts for the opportunity to study the protohistoric people from Angkor Borei. Sincere thanks to the University of Hawai'i-Mānoa students who assisted in laboratory preparations that facilitated skeletal and artifact analyses. Kate Domett graciously shared unpublished Krasang Thmei data, Christophe Pottier provided EFEO reports, and Alison Carter provided the bead photograph. Funding for the LOMAP was provided by the East-West Center, the University of Hawaii, an International Collaborative Research Program Grant (Wenner-Gren Foundation ICR G21), and a Collaborative Grant (National Endowment for the Humanities RZ-2019997). Partial funding was provided by International Archaeological Research Institute, Inc., for the Vat Komnou bioarchaeological research reported here. Voeun Vuthy completed the zooarchaeological research reported here through a Henry Luce Foundation/ACLS study and research fellowship. We thank two anonymous reviewers for their insightful comments and suggestions to improve the quality of this article, and the editors of Asian Perspectives for guiding us through this process. Any errors in this manuscript remain the responsibility of its authors.

\section{NOTES}

1. At sites in the vicinity, a nearly 1:1 male to female ratio was found at Gò Ô Chùa, Vietnam (21 males, 20 females), while only one out of 42 individuals could be sexed at Prohear, Cambodia (Krais et al. 2012:113)

\section{REFERENCES CITED}

Belcher, William R.

1998 Fish Exploitation of the Baluchistan and Indus Valley Traditions: An Ethnoarchaeological Approach to the Study of Fish Remains. Ph.D. diss. Department of Anthropology, University of Wisconsin-Madison.

BELLINA, BÉRÉNICE

2014 Maritime silk road ornament industries: Socio-political practices and cultural transfers in the South China Sea. Cambridge Archaeological Journal 24(2):345-377.

Bellina, Bérénice, and Ian Glover

2004 The archaeology of early contact with India and the Mediterranean world, from the fourth century B.C. to the fourth century A.D., in Southeast Asia: From Prehistory to History: 68-88, ed. Ian Glover and Peter Bellwood. New York: RoutledgeCurzon.

Bentley, R. Alexander

2006 Strontium isotopes from the earth to the archaeological skeleton: A review. Journal of Archaeological Method and Theory 13(3):135-187.

Bentley, R. Alexander, Katharine Cox, Nancy Tayles, Charles Higham, Colin Macpherson, Geoff Nowell, Matthew Cooper, and Tina E. F. Hayes

2009 Community diversity at Ban Lum Khao, Thailand. Asian Perspectives 48:79-97.

Bentley, R. Alexander, Michael Pietrusewsky, Michele Toomay Douglas, and Tim C. Atkinson 2005 Matrilocality during the prehistoric transition to agriculture in Thailand? Antiquity 79 (306):865-881.

Bentley, R. Alexander, Nancy Tayles, Charles Higham, Colin Macpherson, and Tim C. Atkinson 2007 Shifting gender relations at Khok Phanom Di, Thailand: Isotopic evidence from the skeletons. Current Anthropology 48(2):301-314.

Bishor, Paul, Daniel Penny, Miriam T. Stark, and Marian Scott

2003 A 3.5 ka record of paleoenvironments and human occupation at Angkor Borei, Mekong delta, southern Cambodia. Geoarchaeology 18:359-393. 
Bogaard, Amy, Rebecca Fraser, Tim H. E. Heaton, Michael Wallace, Petra Vaiglova, Michael Charles, Glynis Jones, Richard P. Evershed, Amy K. Styring, Niels H. Andersen, Rose-Marie Arbogast, László Bartosiewicz, Armelle Gardeisen, Marie Kanstrup, Ursula Maier, Elena Marinova, Lazar Ninov, Marguerita Schäfer, and Elisabeth Stephan

2013 Crop manuring and intensive land management by Europe's first farmers. Proceedings of the National Academy of Sciences USA 110:12589-12594.

BONG, SOVATH

2003 The Ceramic Chronology of Angkor Borei, Takeo Province, Southern Cambodia. Ph.D. diss. University of Hawai'i at Mānoa.

Brothwell, Don R.

1981 Digging Up Bones: The Excavation, Treatment, and Study of Human Skeletal Remains. New York: Cornell University Press.

Bryant, J. Daniel, Paul L. Koch, Philip N. Froelich, William J. Showers, and Bernard J. Genna

1996 Oxygen isotope partitioning between phosphate and carbonate in mammalian apatite. Geochimica et Cosmochimica Acta 60:5145-5148.

Budd, Paul, Andrew Millard, Carolyn Chenery, Sam lucy, and Charlotte Roberts

2004 Investigating population movement by stable isotope analysis: A report from Britain. Antiquity 78:127-140.

Buikstra, Jane E., and Douglas H. Ubelaker, eds.

1994 Standards for Data Collection from Human Skeletal Remains. Arkansas Archaeological Survey Research Series No. 44. Fayetteville, AR: Arkansas Archaeological Survey.

Calo, Ambra, Bagyo Prasetyo, Peter Bellwood, James W. Lankton, Bernard Gratuze, Thomas Oliver Pryce, Andreas Reinecke, Verena leusch, Heidrun Schenk, Rachel Wood, Rochtri A. Bawono, i Dewa Kompiang Gede, L. K. Ni, Citha Yuliati, Jack Fenner, Christian Reepmeyer, Cristina Castillo, and Alison K. Carter

2015 Sembiran and Pacung on the north coast of Bali: A strategic crossroads for early trans-Asiatic exchange. Antiquity 89:378-396.

Carter, Alison K.

2012 Garnet beads in Southeast Asia: Evidence for local production, in Crossing Borders in Southeast Asian Archaeology. Selected Papers from the 13th International Conference of the European Association of Southeast Asian Archaeologists, Volume 1: 296-306, ed. Dominik Bonatz, Andreas Reinecke, and Mai Lin Tjoa-Bonatz. Singapore: NUS Press.

2015 Beads, exchange networks and emerging complexity: A case study from Cambodia and Thailand (500 B.C.E.-C.E. 500). Cambridge Archaeological Journal 25(4):733-757.

2016 The production and exchange of glass and stone beads in Southeast Asia from 500 B.C.E. to the early second millennium C.E.: An assessment of the work of Peter Francis in light of recent research. Archaeological Research in Asia 6:16-29.

Chhem, Rethy K., Sudhakar K. Venkatesh, Shih-Chang Wang, Kit-Mui Wong, Frank J. Rühli, Edwin P. Y. Siew, Kyle Latinis, and Christophe Pottier

2004 Multislice computed tomography of two 2000-year-old skeletons in a soil matrix from Angkor, Cambodia. Canadian Association of Radiologists Journal 55:235-241.

Clark, Angela L., Nancy Tayles, and Siân E. Halcrow

2014 Aspects of health in prehistoric mainland Southeast Asia: Indicators of stress in response to the intensification of rice agriculture. American Journal of Physical Anthropology 153:484-495.

Clarke, Nigel G., and Robert S. Hirsch

1991a Physiological, pulpal, and periodontal factors influencing alveolar bone, in Advances in Dental Anthropology: 241-266, ed. Marc A. Kelley and Clark Spencer Larsen. New York: John Wiley \& Sons, Inc.

$1991 b$ Tooth dislocation: The relationship with tooth wear and dental abscesses. American Journal of Physical Anthropology 85(3):293-298.

Cohen, Mark Nathan, and George J. Armelagos, eds.

1984 Paleopathology at the Origins of Agriculture. Orlando: Academic Press.

Cohen, Mark Nathan, and Gillian M. M. Crane-Kramer, eds.

2007 Ancient Health: Skeletal Indicators of Agricultural and Economic Intensification. Gainesville, FL: University Press of Florida. 
Cox, Katherine J., R. Alexander Bentley, Nancy Tayles, Hallie R. Buckley, Colin G. Macpherson, AND Matthew J. CoOper

2011 Intrinsic or extrinsic population growth in Iron Age northeast Thailand? Journal of Archaeological Science 38:665-671.

DARK, P.J.C.

1987 Tattooing in Palau. Manuscript on file at Palau Bureau of Arts and Culture, Koror, Palau.

Dias, George J., and Nancy Tayles

1997 'Abscess cavity' - A misnomer. International Journal of Osteoarchaeology 7:548-554.

Domett, Kate M.

2005 The skeletal remains from Krasang Thmey, Banteay Meachey Province, Cambodia. Unpubl. manuscript. James Cook University, Townsville, Australia.

Domett, Kate M., Caitlin Evans, Nancy Tayles, and Nigel Chang

2014 Osteoarthritis in prehistoric Ban Non Wat, Thailand: 2000 years of stasis. Paper presented at the 27th Annual Australasian Society of Human Biology, Australia. Abstract. Bioarchaeology in Southeast Asia and the Pacific: Newsletter 10:25.

Domett, Kate M., Jennifer Newton, Dougald J. W. O’Reilly, Nancy Tayles, Louise Shewan, and NANCY BEAVAN

2013 Cultural modification of the dentition in prehistoric Cambodia. International Journal of Osteoarchaeology 23:274-286.

Domett, Kate M., and Dougald J. W. O’Reilly

2009 Health in Pre-Angkorian Cambodia: A bioarchaeological analysis of the skeletal remains from Phum Snay. Asian Perspectives 48(1):56-78.

Domett, Kate M., and Nancy Tayles

2007 Population health from the Bronze to the Iron Age in the Mun River Valley, Northeastern Thailand, in Ancient Health: Skeletal Indicators of Agricultural and Economic Intensification: 286-299, ed. Mark Nathan Cohen and Gillian M. M. Crane-Kramer. Gainesville, FL: University Press of Florida.

Douglas, Michele Toomay

1996 Paleopathology in Human Skeletal Remains from the Pre-Metal, Bronze, and Iron Ages, Northeastern Thailand. Ph.D. diss. Department of Anthropology, University of Hawai'i at Mānoa.

Douglas, Michele Toomay, and Michael Pietrusewsky

2007 Biological consequences of sedentism and agricultural intensification in northeast Thailand, in Ancient Health: Skeletal Indicators of Agricultural and Economic Intensification (Bioarchaeological Interpretations of the Human Past: Local, Regional, and Global Perspectives): 300-319, ed. Mark Nathan Cohen and Gillian M. M. Crane-Kramer. Gainesville, FL: University Press of Florida.

Douglas, Michele Toomay, Michael Pietrusewsky, and Rona Michi Ikehara-Quebral

1997 Skeletal biology of Apurguan: A pre-Contact (pre-1521) Chamorro site on Guam. American Journal of Physical Anthropology 104(3):291-313.

Dussubieux, Laure, and Bernard Gratuze

2003 Origin et diffusion du verre dans le monde indien et en Asie due Sud-Est: L'importance du dosage des éléments-traces [Origin and diffusion of glass in the Indian World and in Southeast Asia: The importance of variation in trace elements]. Revue d'Archéométrie 27:67-73.

Fehrenbach, Shawn S.

2009 Traditions of Ceramic Technology: An Analysis of the Assemblages from Angkor Borei, Cambodia. M.A. thesis. Department of Anthropology, University of Hawai'i at Mānoa.

Fitzpatrick, Scott M., Greg C. Nelson, and Ryan R. Reeves

2003 The prehistoric chewing of betel nut (Areca catechu) in western Micronesia. People and Culture in Oceania 19:27-37.

Francken, Michael, Joachim Wahl, and Andreas Reinecke

2010 Reflections of a hard life - Burials from Gò Ô Chùa (Vietnam), in Proceedings of the Fourth Meeting of Junior Scientists in Anthropology, Freiburg, 25-28 March 2010: 16-23, ed. Christiane A. Buhl, Felix Engel, Linda Hartung, Mareen Kästner, Alexandra Rüdell, and Christian Weisshaar. Breisgau: The Freiburg University. 
Frelat, Mélanie A., and Caroline Souday

2015 The Bronze Age necropolis of Ko Ta Meas: Insights into the health of the earliest inhabitants of the Angkor region. Bulletins et Mémoires de la Société d'Anthropologie de Paris 27(3):142-157.

Frelat, Mélanie A., Caroline Souday, Nicloas Buchet, Fabrice Demeter, and Christophe Pottier

2016 Corrigendum for The Bronze Age necropolis of Koh Ta Meas: Insights into the health of the earliest inhabitants of the Angkor region. Bulletins et Mémoires de la Société d'Anthropologie de Paris 28(1):98-99.

Hammerle, Esme A.

2004 An Archaeological Study of Ancient Beads from Cambodia. Senior honors thesis. Department of Anthropology, University of Hawai'i at Mānoa.

Higham, Charles F. W.

2014 Early Mainland Southeast Asia: From First Humans to Angkor. Bangkok: River Books.

HiLlson, Simon

2008 Dental pathology, in Biological Anthropology of the Human Skeleton, $2^{\text {nd }}$ ed.: 301-340, ed. Mary Anne Katzenberg and Shelley R. Saunders. New York: John Wiley \& Sons.

Hu, Yaowu, Stanley H. Ambrose, and Changsui Wang

2006 Stable isotopic analysis of human bones from Jiahu Site, Henan, China: Implications for the transition to agriculture. Journal of Archaeological Science 33:1319-1330.

IKeHARA-Quebral, Rona Michi

2010 An Assessment of Health in Early Historic (200 B.C. to A.D. 200) Inhabitants of Vat Komnou, Angkor Borei, Southern Cambodia. Ph.D. diss. University of Hawai'i at Mānoa.

2012 Early Historic inhabitants of Vat Komnou, Angkor Borei, Southern Cambodia: A bioarchaeological assessment of health. Unpubl. paper presented at the 77th Annual Meeting of the Society for American Archaeology, 18-22 April 2012, Memphis, TN.

Ikehara-Quebral, Rona, Miriam T. Stark, William Belcher, Voeun Vuthy, John Krigbaum, Michael Pietrusewsky, and Michele Toomay Douglas

2013 Biocultural practices during the transition to history at Angkor Borei, Cambodia. Unpubl. paper presented at the 78th Annual Meeting of the Society for American Archaeology, 3-7 April 2013, Honolulu, HI.

ISHIZAWA, YOSHIAKI

1995 Chinese chronicles of the first-fifth century A.D. Funan, southern Cambodia, in South East Asia E China: Art, Interaction \& Commerce: 11-31, ed. Rosemary Scott and John S. Guy. Colloquies on Art \& Archaeology in Asia No. 17. London: Percival David Foundation of Chinese Art, University of London.

Junker, LAura LeE

2004 Political economy in the historic period chiefdoms and states of Southeast Asia, in Archaeological Perspectives on Political Economies: 223-251, ed. Gary M. Feinman and Linda M. Nicholas. Salt Lake City, UT: University of Utah Press.

KIM, NAM C.

2013 Lasting monuments and durable institutions: Labor, urbanism, and statehood in northern Vietnam and beyond. Journal of Archaeological Research 21(1):217-267.

King, Charlotte L., R. Alexander Bentley, Nancy Tayles, Una Strand-Viôarsdóttir, Geoff Nowell, and Colin G. Macpherson

2013 Moving peoples, changing diets: Isotopic differences, migration and subsistence changes in the Upper Mun River Valley, Thailand. Journal of Archaeological Science 40:1681-1688.

King, Christopher A., and Lynette Norr

2006 Palaeodietary change among pre-state Metal Age societies in northeast Thailand: A study using bone stable isotopes, in Bioarchaeology of Southeast Asia: 242-262, ed. Marc Oxenham and Nancy Tayles. New York: Cambridge University Press.

Kohn, Matthew J.

1996 A predictive model for animal $\delta^{18} \mathrm{O}$ : Accounting for diet and physiological adaptation. Geochimica et Cosmochimica Acta 60:4811-4829.

Krais, Simone, Andreas Reinecke, Seng Sonetra, and Vin Laychour

2012 The biological anthropology of the early Iron Age site of Prohear (Cambodia). Zeitschrift für Archäologie Außereuropäischer Kulturen 4:103-125. 
KräMER, Augustin

1926 Palau. Ergebnisse der Südsee-Expedition [Results of the South Sea Expedition] 1908-1910. Part II. Ethnographie [Ethnography]: Section B. Mikronesien [Micronesia] Vol. 3, No. 3, ed. G. Thilenius. Hamburg: Friederichsen, De Gruyter \& Co.

Krigbaum, John R., R. Alexander Bentley, Miriam T. Stark, Michael Pietrusewsky, and William BelCHER

2008 New perspectives on diet, ecology, and residence during the transition to history in the Mekong Delta. Unpubl. paper presented at the 73rd Annual Meeting of the Society for American Archaeology, 26-30 March 2008, Vancouver.

Kusaka, Soichiro, Atsushi Ando, Takanori Nakano, Takakazu Yumoto, Eriko Ishimaru, Minoru Yoneda, Fujio Hyodo, and Kazumichi Katayama

2009 Strontium isotope analysis on the relationship between ritual tooth ablation and migration among the Jomon people in Japan. Journal of Archaeological Science 36:2289-2297.

Larsen, Clark Spencer

2002 Bioarchaeology: The lives and lifestyles of past people. Journal of Archaeological Research 10: 119-166.

2015 Bioarchaeology: Interpreting Behavior from the Human Skeleton. $2^{\text {nd }}$ ed. New York: Cambridge University Press.

Larsen, Clark Spencer, and George R. Milner, eds.

1994 In the Wake of Contact: Biological Responses to Conquest. New York: Wiley-Liss, Inc.

Le, THI LIEN

2011 Hindu deities in southern Vietnam: Images on small archaeological artefacts, in Early Interactions Between South and Southeast Asia: Reflections on Cross-Cultural Exchange: 407-431, ed. Pierre-Yves Manguin, A. Mani, and Geoff Wade. Singapore: Institute for Southeast Asian Studies, National University of Singapore.

Lee-Thorp, Julia A.

2008 On isotopes and old bones. Archaeometry 50(6):925-950.

LÉvesque, RoDrigue, ED.

1996 History of Micronesia: A Collection of Source Documents. Volume 6 Revolts in the Marianas, 1673-1678. Québec: Lévesque Publications.

Lieverse, Angela R.

1999 Diet and the aetiology of dental calculus. International Journal of Osteoarchaeology 9:219-232.

Lieverse, Angela R., David W. Link, Vladimir Ivanovich Bazaliskiy, Olga Ivanovna Goriunova, and ANDRZEJ W. WeBER

2007 Dental health indicators of hunter-gatherer adaptation and cultural change in Siberia's CisBaikal. American Journal of Physical Anthropology 134:323-339.

LuKaCS, JOHN R.

1995 The 'caries correction factor': A new method of calibrating dental caries rates to compensate for antemortem loss of teeth. International Journal of Osteoarchaeology 5(2):151-156.

Machicek, Michelle L., and Jeremy J. Beach

2013 Stresses of life: A preliminary study of degenerative joint disease and dental health among ancient populations of inner Asia, in Bioarchaeology of East Asia: Movement, Contact, Health: 246-264, ed. Kate Pechenkina and Marc Oxenham. Gainesville, FL: University Press of Florida.

Manguin, Pierre-Yves

2004 The archaeology of early maritime polities of Southeast Asia, in Southeast Asia: From Prehistory to History: 282-313, ed. Ian Glover and Peter Bellwood. New York: RoutledgeCurzon.

2009 The archaeology of Funan in the Mekong River delta: The "Oc Eo Culture" of Vietnam, in Arts of Ancient Viet Nam: From River Plain to Open Sea: 100-118, ed. Nancy Tingley. Houston, TX: Asia Society, Museum of Fine Arts.

Manguin, Pierre-Yves, and Si Khai Vo

2000 Excavations at the Ba The/Oc Eo complex (Vietnam): A preliminary report on the 1998 campaign, in Southeast Asian Archaeology 1998: 107-122, ed. Wibke Lobo and Stephanie Reimann. Hull, U.K.: Centre for Southeast Asian Studies, University of Hull. 
Milner, George R., and Clark Spencer Larsen

1991 Teeth as artifacts of human behavior: Intentional mutilation and accidental modification, in Advances in Dental Anthropology: 357-378, ed. Marc A. Kelly and Clark Spencer Larsen. New York: Wiley-Liss.

NeLsen, Kirsten M.

1999 The Dental Health of the People from Noen U-Loke: A Prehistoric Iron Age Site in Northeast Thailand. M.S. thesis. University of Otago, Dunedin, New Zealand.

Nelsen, Kirsten M., Nancy Tayles, and Kate M. Domett

2001 Missing lateral incisors in Iron Age South-East Asians as possible indicators of dental agenesis. Archives of Oral Biology 46:963-971.

Newton, JenNifer

2014 Health, Diet and Migration Prior to the Establishment of the Pre-Angkorian Civilisation of Southeast Asia. Ph.D. diss. James Cook University, Queensland.

Newton, Jennifer, and Kate M. Domett

2014 The biocultural context of dental modification in prehistoric Southeast Asia. Abstract. American Journal of Physical Anthropology S58:195.

Newton, Jennifer, Kate M. Domett, Dougald J. W. O’Reilly, and Louise Shewan

2013 Dental health in Iron Age Cambodia: Temporal variations with rice agriculture. International Journal of Paleopathology 3:1-10.

Nuttonson, Michael Yakovlevich

1963 The Physical Environment and Agriculture of Vietnam, Laos, and Cambodia: A Study Based on Field Survey Data and on Pertinent Records, Material, and Reports. Washington, D.C.: American Institute of Crop Ecology.

Office of Planning and Statistics

1995 Republic of Palau, 1995 Omelamch el Buuch Survey (Betel Nut Chewing). Report on file at International Archaeological Research Institute, Koror, Palau.

Olivier, Georges

1968 Anthropolgie des Cambodgiens [Anthropology of the Cambodians]. Paris: École Française D'Extrême-Orient.

O’Reilly, Dougald J. W.

2004 Excavations at Phum Snay, Cambodia. Bulletin of the Indo-Pacific Prehistory Association 24: 129-132.

2014 Increasing complexity and the political economy model: A consideration of Iron Age moated sites in Thailand. Journal of Anthropological Archaeology 35:297-309.

O’Reilly, Dougald J. W., Angela von den Driesch, and Voeun Vuthy

2006 Archaeology and archaeozoology of Phum Snay: A late prehistoric cemetery in northwestern Cambodia. Asian Perspectives 45(2):188-211.

Ortner, Donald J., and Walter G. J. Putschar

1981 Identification of Pathological Conditions in Human Skeletal Remains. Smithsonian Contributions to Anthropology, No. 28. Washington, D.C.: Smithsonian Institution Press.

OXenham, Marc F.

2000 Health and Behaviour during the Mid-Holocene and Metal Period of Northern Viet Nam. Ph.D. thesis. Northern Territory University, Darwin.

Oxenham, Marc F., and Kate M. Domett

2011 Palaeohealth at Man Bac, in Man Bac: The Excavation of a Neolithic Site in Northern Vietnam, Terra Australis 33: 77-93, ed. Marc F. Oxenham, Hirofumi Matsumura, and Nguyen Kim Dung. Canberra: Australian National University E Press.

Oxenham, Marc F., Cornelia Locher, Lan Cuong Nguyen, and Kim Thuy Nguyen

2002 Identification of Areca catechu (betel nut) residues on the dentitions of Bronze Age inhabitants of Nui Nap, northern Vietnam. Journal of Archaeological Science 299:909-915.

Oxenham, Marc, Kim Thuy Nguyen, and Lan Cuong Nguyen

2005 Skeletal evidence for the emergence of infectious disease in Bronze and Iron Age Northern Vietnam. American Journal of Physical Anthropology 126:359-376. 
Oxenham, Marc, Lan Cuong Nguyen, and Kim Thuy Nguyen

2006 The oral health consequences of the adoption and intensification of agriculture in Southeast Asia, in Bioarchaeology of Southeast Asia: 263-289, ed. M. Oxenham and N. Tayles. Cambridge: Cambridge University Press.

Pechenkina, Ekaterina A., Stanley H. Ambrose, Ma Xiaolin, and Robert A. Benfer, Jr.

2005 Reconstructing northern Chinese Neolithic subsistence practices by isotopic analysis. Journal of Archaeological Science 32:1176-1189.

Pietrusewsky, Michael, and Michele Toomay Douglas

1993 Tooth ablation in Old Hawai'i. Journal of the Polynesian Society 102(3):255-272.

2002 Ban Chiang, A Prehistoric Site in Northeast Thailand. I: The Human Skeletal Remains. Philadelphia: University of Pennsylvania Museum of Archaeology and Anthropology.

Pietrusewsky, Michael, Michele Toomay Douglas, Marilyn Swift, Randy Harper, and Michael A. FLeming

2011 An assessment of health and lifestyle among prehistoric Chamorro from Tinian Island in the Northern Mariana Islands. Abstract. American Journal of Physical Anthropology S52:238-239.

2014 Health in ancient Mariana Islanders: A bioarchaeological perspective. Journal of Island and Coastal Archaeology 9:319-340.

Pietrusewsky, Michael, and Rona Michi Ikehara-Quebral

2006 The bioarchaeology of the Vat Komnou cemetery, Angkor Borei, Cambodia. Bulletin of the Indo-Pacific Prehistory Association 26:86-97.

Pietrusewsky, Michael, Adam Lauer, Cheng-Hwa Tsang, Kuang-Ti Li, and Michele Toomay Douglas

2014 Tooth ablation in early Neolithic skeletons from Taiwan. Abstract. American Journal of Physical Anthropology S58:207.

POWELl, MARY L.

1985 The analysis of dental wear and caries for dietary reconstruction, in The Analysis of Prehistoric Diets: 307-338, ed. Robert I. Gilbert Jr. and James H. Mielke. Orlando: Academic Press.

REINECKE, ANDREAS

2012 The prehistoric occupation and cultural characteristics of the Mekong Delta during the preFunan periods, in Crossing Borders: Selected Papers from the 13th International Conferences of the European Association of Southeast Asian Archaeologists, Volume 1: 239-256, ed. Mai Lin TjoaBonatz, Andreas Reinecke, and Dominik Bonatz. Singapore: NUS Press.

Reinecke, Andreas, Vin Laychour, and Seng Sonetra

2009 The First Golden Age of Cambodia: Excavation at Prohear. Bonn: Thomas Müntzer.

Rogers, Juliet, Tony Waldron, Paul Dieppe, and Iain Watt

1987 Arthropathies in palaeopathology: The basis of classification according to most probable cause. Journal of Archaeological Science 14:179-193.

Sangvichien, Sood J., Patai Sirigaroon, and J. Balslev Jørgensen

1969 Archaeological Excavations in Thailand. Vol. 3: Ban Kao. Part 2: The Prehistoric Thai Skeletons. Copenhagen: Munksgaard.

Sangvichien, Sood J., Vasan Srisurin, and Vebra Watthanayingsakul

1985 Estimation of stature of Thai and Chinese from the length of the femur, tibia, and fibula. Siriraj Hospital Gazette 37:215-218.

Sangvichien, Sood J., Vasan Srisurin, Vebra Watthanayingsakul, Pattraporn Theerarattakul, and

SUNTHRON, RAKVANICHPONG

n.d. Equations for estimation of the Thai's stature from the length of long bones (a preliminary report). Unpubl. manuscript.

Sarkar, Anindya, Arati Deshpande Mukherjee, M. K. Bera, B. Das, Navin Juyal, P. Morthekai,

R. D. Deshrande, V. S. Shinde, and L. S. Rao

2016 Oxygen isotope in archaeological bioapatites from India: Implications to climate change and decline of Bronze Age Harappan civilization. Scientific Reports 6: Article number 26555.

Stark, Miriam T.

1998 The transition to history in the Mekong delta: A view from Cambodia. International Journal of Historical Archaeology 2(3):175-203.

2001a Southeast Asia late prehistoric: 2500-1500 bp, in Encyclopedia of Prehistory, Vol. 3: East Asia and Oceania: 160-205, ed. Peter N. Peregrine and Melvin Ember. New York: Plenum. 
$2001 \mathrm{~b}$ Some preliminary results of the 1999-2000 archaeological field investigations at Angkor Borei, Takeo Province. Journal of Khmer Studies 2001:19-35.

2003 Angkor Borei and the archaeology of Cambodia's Mekong delta, in Art E Archaeology of Fu Nan: Pre-Khmer Kingdom of the Lower Mekong Valley: 88-105, ed. James C. M. Khoo. Bangkok: Orchid Books.

2004 Pre-Angkorian and Angkorian Cambodia, in Southeast Asia: From Prehistory to History: 89-119, ed. Ian Glover and Peter Bellwood. New York: RoutledgeCurzon.

2006 a Early mainland Southeast Asian landscapes in the first millennium A.D. Annual Review of Anthropology 35:407-432.

$2006 b$ Pre-Angkorian settlement trends in Cambodia's Mekong delta and the Lower Mekong Archaeological Project. Bulletin of the Indo-Pacific Prehistory Association 26:98-109.

2006c Textualized places, Pre-Angkorian Khmers, and historicized archaeology, in Excavating Asian History: Interdisciplinary Studies in Archaeology and History: 308-326, ed. Norman Yoffee and Bradley L. Cromwell. Tucson, AZ: University of Arizona Press.

2017 Globalizing Early Southeast Asia, in The Routledge Handbook of Archaeology and Globalization: 707-711, ed. Tamar Hodos. London: Routledge.

Stark, Miriam T., and Sovath Bong

2001 Recent research on emergent complexity in Cambodia's Mekong. Bulletin of the Indo-Pacific Prehistory Association 21:85-98.

Tamura, Toru, Yoshiki Saito, Sotham Sieng, Bunnarin Ben, Meng Kong, Im Sim, Sokuntheara Choup, ANd Bumio Акibo

2009 Initiation of the Mekong River Delta at $8 \mathrm{ka}$ : Evidence from the sedimentary succession in the Cambodian lowland. Quaternary Science Reviews 28:327-344.

TAYles, NANCy

1996 Tooth ablation in prehistoric Southeast Asia. International Journal of Osteoarchaeology 6:333-345.

Tayles, Nancy, Kate M. Domett, and Kirsten M. Nelsen

2000 Agriculture and dental caries? The case of rice in prehistoric Southeast Asia. World Archaeology 32:68-83.

Tayles, Nancy, Siân E. Halcrow, and Kate M. Domett

2007 The people of Noen U-Loke, in The Origins of the Civilization of Angkor. Volume II. The Excavations of Noen U-Loke and Non Muang Kao: 243-304, ed. Charles F. W. Higham, Amphan Kijngam, and Sarah Talbot. Thailand: The Thai Fine Arts Department.

Voeun Vuthy and Seng Sonetra

2006 Fish remains from Koh Ta Meas site, in Mission Archéologique Franco-Khmère sur l'Aménagement du Territoire Angkorien, Campagne 2006 Rapport [French-Khmer Archaeological Mission in the Angkorian Territory, Report on the 2006 Campaign]: 129-151, ed. Christophe Pottier. Siem Reap: Ecole Française d'Extreme-Orient.

Voeun Vuthy and Angela von den Driesch

2004 Fish remains from Angkor Borei archaeological site in the Mekong delta, Cambodia, in Southeast Asian Archaeology: Wilhelm G. Solheim II Festschrift: 400-410, ed. Victor Paz. Quezon City: University of the Philippines Press.

Weber, Steve, Heather Lehman, Timothy Barela, Sean Hawks, and David Harriman

2010 Rice or millets: Early farming strategies in prehistoric central Thailand. Archaeological and Anthropological Sciences 2:79-88.

Yu, Christine, and Paul V. AbBott

2007 An overview of the dental pulp: Its functions and responses to injury. Australian Dental Journal Supplement 52(1 Suppl.):S4-S16.

Zumbroich, Thomas J.

2007 The origin and diffusion of betel chewing: A synthesis of evidence from South Asia, Southeast Asia and beyond. eJournal of Indian Medicine 1:87-140. URL: rjh.ub.rug.nl/eJIM/article/view/ $24712 / 22162$.

Zumbroich, Thomas J., and Analyn Salvador-Amores

2009 'When black teeth were beautiful': The history and ethnography of dental modifications in Luzon, Philippines. Stvdia Asiatica 10:125-165. 